U.S.Army

Coast. Eng. Res.

C+r

MP $8-75$

$(A D-A 016948)$

Effects of Engineering Activities on

the Ecology of Pismo Clams

by

James Nybakken and Mark Stephenson

MISCELLANEOUS PAPER NO. 8-75

SEPTEMBER 1975
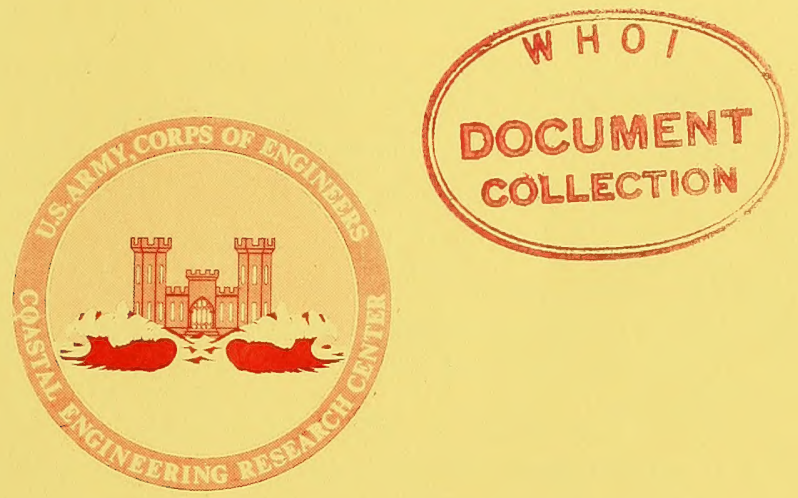

Approved for public release;

distribution unlimited.

Prepared for

U. S. ARMY, CORPS OF ENGINEERS

$G B$

COASTAL ENGINEERING

450

.43

RESEARCH CENTER

Kingman Building

no. $8-75$

Fort Belvoir, Va. 22060 
Reprint or republication of any of this material shall give appropriate credit to the U.S. Army Coastal Engineering Research Center.

Limited free distribution within the United States of single copies of this publication has been made by this Center. Additional copies are available from:

\section{National Technical Information Service ATTN: Operations Division 5285 Port Royal Road Springfield, Virginia 22151}

Contents of this report are not to be used for advertising, publication, or promotional purposes. Citation of trade names does not constitute an official endorsement or approval of the use of such commercial products.

The findings in this report are not to be construed as an official Department of the Army position unless so designated by other authorized documents. 


\begin{tabular}{|c|c|}
\hline REPORT DOCUMENTATION PAGE & $\begin{array}{c}\text { READ INSTRUCTIONS } \\
\text { BEFORE COMPLETING FORM }\end{array}$ \\
\hline $\begin{array}{l}\text { 1. REPORT NUMBER } \\
\text { MP } 8-75\end{array}$ & 3. RECIPIENT'S CATALOG NUMBER \\
\hline \multirow{2}{*}{$\begin{array}{l}\text { 4. TITLE (and Subtitie) } \\
\text { EFFECTS OF ENGINEERING ACTIVITIES ON } \\
\text { THE ECOLOGY OF PISMO CLAMS }\end{array}$} & $\begin{array}{l}\text { 5. TYPE OF REPORT \& PERIOD COVERED } \\
\text { Miscellaneous Paper }\end{array}$ \\
\hline & 6. PERFORMING ORG. REPORT NUMBER \\
\hline $\begin{array}{l}\text { 7. AUTHOR(o) } \\
\text { James Nybakken } \\
\text { Mark Stephenson }\end{array}$ & 8. CONTRACT OR GRANT NUMBER(s) \\
\hline $\begin{array}{l}\text { 9. PERFORMING ORGANIZATION NAME AND ADDRESS } \\
\text { MOSS Landing Marine Laboratories. } \\
\text { Moss Landing, California } 95039\end{array}$ & $\begin{array}{l}\text { 10. PROGRAM ELEMENT, PROJECT, TASK } \\
\text { AREA \& WORK UNIT NUMBERS }\end{array}$ \\
\hline \multirow{2}{*}{$\begin{array}{l}\text { 11. CONTROLLING OFFICE NAME AND ADDRESS } \\
\text { Department of the Army } \\
\text { Coastal Engineering Research Center (CERRE-EC) } \\
\text { Kingman Building, Fort Belvoir, VA } 22060\end{array}$} & $\begin{array}{l}\text { 12. REPORT DATE } \\
\text { September } 1975\end{array}$ \\
\hline & $\begin{array}{l}\text { 13. NUMBER OF PAGES } \\
65\end{array}$ \\
\hline \multirow{2}{*}{ 14. MONITORING AGENCY NAME \& ADDRESS(If different from Controlling Office) } & $\begin{array}{l}\text { 15. SECURITY CLASS. (of this roport) } \\
\text { UNCLASSIFIED }\end{array}$ \\
\hline & $\begin{array}{l}\text { 15a. DECLASSIFICATION/DOWNGRADING } \\
\text { SCHEDULE }\end{array}$ \\
\hline
\end{tabular}

16. DISTRIBUTION STATEMENT (of this Report)

Approved for public release; distribution unlimited.

17. DISTRIBUTION STATEMENT (of the abstract entered in Block 20, if different from Report)

18. SUPPLEMENTARY NOTES

19. KEY WORDS (Continue on reverse side if necessary and identify by block number)

Pismo Clams

Monterey Bay, California

Ecology

20. ABSTRACT (Continue on roverse side if neceseary and identity by block number)

Three aspects of the ecology of Pismo clams (Tivela stultorum) were investigated in Monterey Bay, California: distribution, reproduction cycle, and age and growth.

Pismo clam populations were found to be restricted to bay areas between the Salinas River and Santa Cruz. Highest densities recorded were intertidal, and subtidal clam beds were few and with low densities. Most clams appeared 
20. Abstract (continued).

randomly dispersed, and different size classes did not show a vertical separation.

The presence and absence of clams were shown to be correlated with beach slope and grain size.

Pismo clams mature in their second year in Monterey Bay, and the primary spawning time is in September and October.

The growth rate is more rapid in young clams and varies throughout the year in all size classes but is most rapid in the summer and fall. 
This report is published to inform coastal engineers of the ecological effects of coastal engineering activities. The results of this 2-year study can serve as a guide in sampling Pismo clam populations along the California coast; the density and distribution of the clam in Monterey Bay, and knowledge of spawning times can aid in project planning to avoid harming an important fishing resource. The work was carried out under the coastal ecology research program of the U.S. Army Coastal Engineering Research Center (CERC).

The report was prepared by Dr. James Nybakken and Mr. Mark Stephenson, of Moss Landing Marine Laboratories, Moss Landing, California, under CERC Contract No. DACW72-72-C-0016.

Mr. R.M. Yancey, Chief, Ecology Branch, was the CERC contract monitor for the report, under the general supervision of Mr. R.P. Savage, Chief, Research Division.

Comments on this publication are invited.

Approved for publication in accordance with Public Law 166, 79th Congress, approved 31 July 1945, as supplemented by Public Law 172, 88th Congress, approved 7 November 1963.

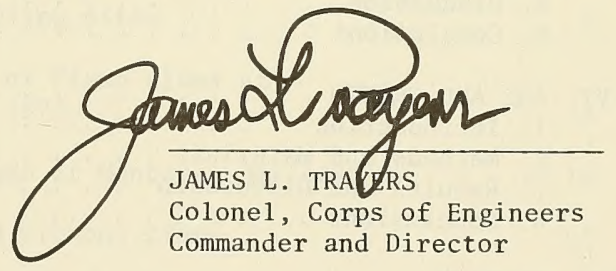


I INTRODUCTION . . . . . . . . . . . . . 7

II DISTRIBUTION . . . . . . . . . . . . . 7

1. Introduction . . . . . . . . . . . 7

2. Methods and Materials ............ 8

3. Results ............... . . . 10

4. Discussion . . . . . . . . . . . . . . 15

5. Conclusions . . . . . . . . . . . . . 18

Ii I Sediment StUdies . . . . . . . . . . . . . . . . . . 19

1. Introduction . . . . . . . . . . . . . . 19

2. Methods and Materials . . . . . . . . . . . . 19

3. Results ................. . . 19

4. Discussion . . . . . . . . . . . 20

5. Conclusions .. . . . . . . . . . . . 24

IV SEA OTTER PREDATION ON PISMO CLAMS . . . . . . . . . . 24

1. Introduction . . . . . . . . . . . . . . . . . 24

2. Methods and Materials ............ . 24

3. Results ................ . . 25

4. Discussion ............... . . . 25

5. Conclusion ............... . . 26

V REPRODUCTIVE CYCLE . . . . . . . . . . . . . 26

1. Introduction . . . . . . . . . . . . 26

2. Methods and Materials............ 27

3. Results . . . . . . . . . . . . . 27

4. Discussion ... . . . . . . . . . . 35

5. Conclusions ................ . . . 44

VI AGE AND GROWTH . . . . . . . . . . . . . . . . 44

1. Introduction . . . . . . . . . . . . . . 44 44

2. Methods and Materials . . . . . . . . . . . . . 44

3. Results and Discussion ............ . . 47

4. Conclusions . . . . . . . . . . . . . 51

VII SUMMARY . . . . . . . . . . . . . . 54

LITERATURE CITED . . . . . . . . . . . . . 55

APPENDIX . . . . . . . . . . . . . . 66 61 


\section{TABLES}

1 Intertidal-subtidal densities of Pismo clams in

Monterey Bay

2 Tests of significant differences among densities of

Pismo clams in different areas . . . . . . . . . . . 12

3 Tests of spatial dispersion of Pismo clams . . . . . . . . 17

4 Correlation coefficients $\left(\mathrm{r}_{s}\right)$ between clams and sediment parameters . . . . . . . . . . . . . 20

5 Beach profile slopes (foot per foot) of beaches with and without clams . . . . . . . . . . . . . 21

6 Number of clams in each stage of gonadal maturity . . . . . 31

7 Temperature, chlorophyll a, phaeo-pigment and stage of gonadal maturity in Monterey Bay . . . . . . . . . . . . 42

8 Calculation of $\mathrm{Kg}$, the mean daily growth rate . . . . . . 49

9 Comparison of average size of year classes at Monterey

Bay Academy . . . . . . . . . . . . . . . . 53

\section{FIGURES}

1 Map of Monterey Bay and sampling sites . . . . . . . . . . 9

2 Size-frequency distribution of Pismo clams at selected beaches, 1972 and 1973 . . . . . . . . . 13

3 Vertical distribution of clams at Monterey Bay Academy . . . . 16

4 Profiles of beaches with and without clams . . . . . . . 22

5 Female gonad in the inactive stage . . . . . . . . . . . 28

6 Female gonad in the early active stage . . . . . . . . . 28

7 Female gonad in the late active stage . . . . . . . . . 29

8 Female gonad in the ripe or mature stage . . . . . . . . . 29 
9 Female gonad in the partly spent stage . . . . . . . . . 30

10 Female gonad in the spent stage . . . . . . . . . . 30

11 Percent of females in early active stage . . . . . . . . . 32

12 Percent of females in Zate active stage . . . . . . . . . 33

13 Percent of females in ripe stage . . . . . . . . . . . 34

14 Percent of females in partzy spent stage . . . . . . . . . . 36

15 Percent of females in spent stage . . . . . . . . . . . 37

16 Percent of Pismo clams in inactive stage . . . . . . . . . . 38

17 Size of female, male, and immature Pismo clams . . . . . . . 39

18 Hermaphrodite gonad . . . . . . . . . . . . . . 40

19 Regression lines for growth rates of marked populations of Pismo clams .. . . . . . . . . . . . . 48 48

20 Mean daily arithmetic growth rate $(\mathrm{Kg})$ of Pismo clams . . . 50

21 Age structure of Pismo clams at Monterey Bay Academy, October 1973 . . . . . . . . . . . . . . . . 52 


\title{
EFFECTS OF ENGINEERING ACTIVITIES ON
} THE ECOLOGY OF PISMO CLAMS

\author{
by \\ James Nybakken and Mark Stephenson
}

\section{INTRODUCTION}

The Pismo clam (Tivela stultomum) is an important sports and commercial bivalve mollusk inhabiting open sand beaches from Half Moon Bay, California, to Socorro Island, Mexico (Herrington, 1930). This study covers the gonad and spawning cycle, distribution, and reproduction cycle of the Pismo clam, summarizing the results obtained during a 2-year study from January 1972 to January 1974. However, because of vandalism and weather, the growth shelter section is incomplete.

\section{DISTRIBUTION}

\section{Introduction.}

Before this study, information on the qualitative and quantitative distribution of Pismo clams in Monterey Bay was 1 imited. The California Department of Fish and Game provided an aerial survey of Monterey Bay conducted during low tide on 15 January 1969. At that time 87 clammers were found between the Salinas River mouth and Elkhorn Slough, 57 between E1khorn Slough and the Pajaro River, 156 between the Pajaro River and Monterey Bay Academy, and 62 between Monterey Bay Academy and Rio del Mar (Dahlstrom, 1973, personal communication). Assuming that clammers are found where clams are, a rough estimate was made on the location of clams in Monterey Bay.

The only quantitative data available were obtained by the California Department of Fish and Game in 1968. Transects were used to acquire the data by digging a 6 -inch-wide by 6 -inch-deep trench from high tide level down to low tide level. Six clams at Sunset State Beach, four clams about 1 mile and six clams about 1.5 miles south of Sunset State Beach, and three clams at Zmudowski State Beach (Dahlstrom, 1973, personal communication) were obtained from these transects. However, the transects were of limited value for estimating the density and dispersion patterns due to the small area surveyed and the lack of replicates. It was necessary to devise a new system to adequately sample the clam population so these estimates could be made. Since the California Department of Fish and Game surveys covered only a few areas, it was also necessary to sample representative sites for clams around the bay.

Although there were rumors of extensive subtidal populations of Pismo clams in various localities in Monterey Bay, these beds were not documented. Determination of the beds is important for protection from exploitation or damage from dredging or dredged material if the 
populations are large and the major source of gametes supplying recruitment to the heavily clammed intertidal areas. Fitch (1965) provided the only evidence of the beds, reporting large numbers of clams at one subtidal location in southern California.

This study determines the intertidal and subtidal areas of presence and absence of Pismo clams in Monterey Bay and, for those areas where the clams were present, estimates density, dispersion pattern, and vertical distribution. A comparison was also made of physical characteristics of beaches with and without clams.

2. Methods and Materia1s.

Intertidal samplings were taken at 10 randomly selected locations in Monterey Bay (Fig. 1). Sampling at eight locations began during June, July, and August 1972. A sample was taken at the Salinas River mouth in November 1972, and at Fort Ord in December 1972. Rio del Mar, Monterey Bay Academy, Sunset State Beach, Zmudowski State Beach, and Moss Landing were resampled during June and July 1973. Twenty 1-squaremeter samples from each station were randomly selected within a 18- by 24-meter grid placed so the lowest edge was at approximately the -1.0 -foot tidal level. Each square meter was raked with a small hand rake with tines that penetrated 6 inches. A 0.25 -square-meter area was subsampled by taking 13 cores ( 0.018 square meter) that penetrated 6 inches into the sand. The contents were emptied into a sieve box and sieved in the surf (0liver and Slattery, 1973). The rake provided an adequate sample of clams greater than 39 millimeters in length since these clams could not pass between the tines. The core samples were quantitative for clams from 10 to 39 millimeters long. The lower limit was dictated by the mesh size of the sieve box. Each clam was measured, the quadrat of occurrence noted, and then reburied. Five sediment cores were also taken at each of the distribution study sites.

Subtidal samplings were taken offshore of each intertidal sampling station at the -15-foot tidal level in July, August, and September 1972, except for the Fort Ord station which was not sampled due to heavy surf. Because of wave action, the -15-foot tidal level was the shallowest depth the samples could be obtained from a boat. No subtidal sampling was done in 1973 because of the low number of clams found in 1972 .

The sampling device was a modified portable gold dredge (Brett, 1964), which has also been used in surveys for macrofauna (Hughes and Thomas, 1971 ) and has been compared with other benthic samplers (Hodgson, 1973, unpublished). The gold dredge is powered by a 7-horsepower portable gasoline engine which pumps high-pressure water to the diver below. Water enters the middle of an L-shaped tube 6 inches in diameter and discharges at one end of the tube, causing a powerful suction at the other end which lifts sediment and clams. A bag of 3-millimeter nylon mesh is attached to the discharge end to catch the clams, and sediment is expelled through the mesh leaving the clams and larger particles. Twenty 1-square-meter samples to a depth of 6 inches were taken at each 


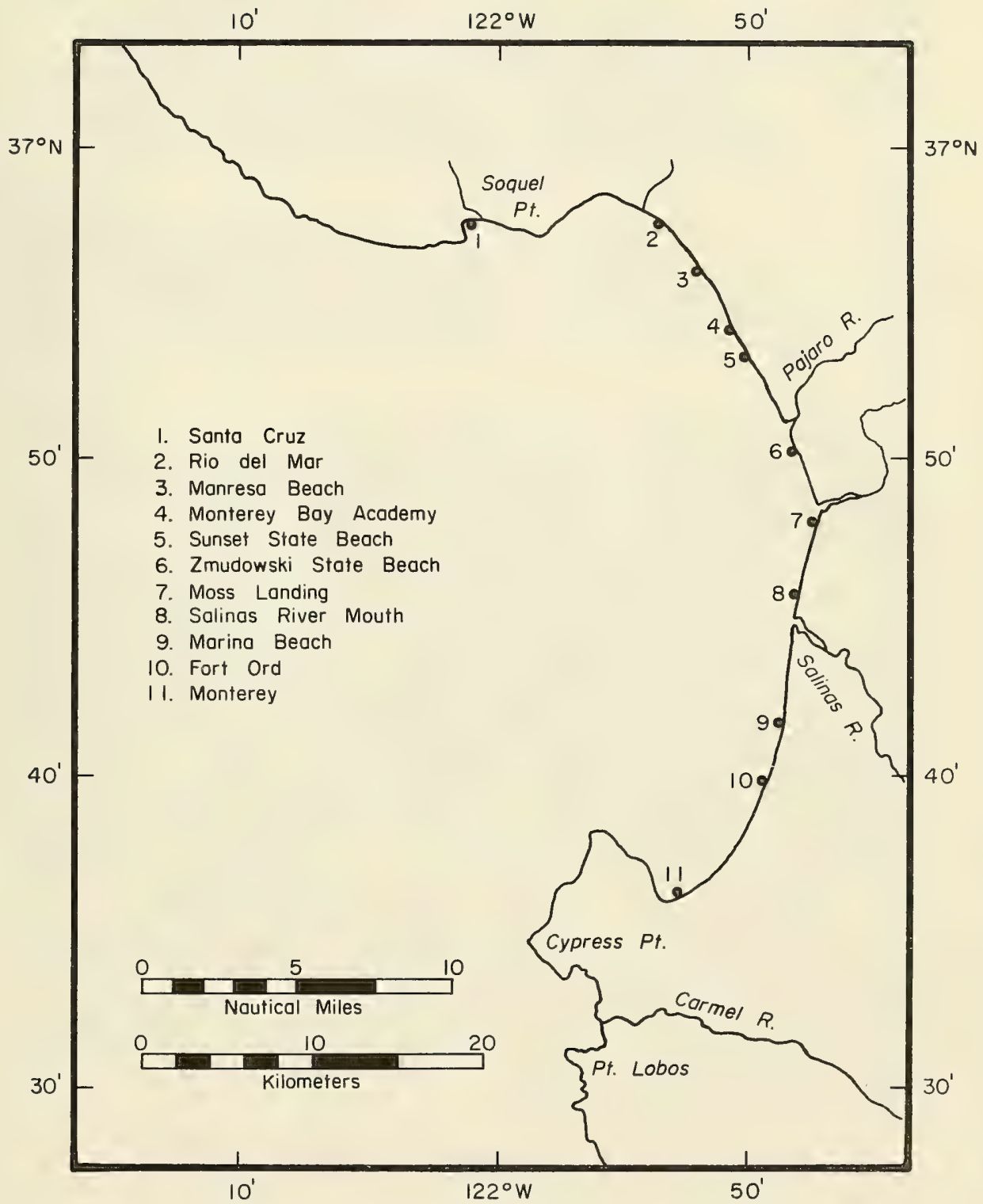

Figure 1. Map of Monterey Bay and sampling sites. 
station. Sample locations were selected at random with the diver sampling a square-meter area, moving about 10 to 15 feet away for the next sample. The divers introduced little bias in the selection of sample sites because visibility was usually limited to 5 feet or less, the bottom was homogenous, and clam siphons were not visible. The sample was collected in the mesh bag, brought to the boat, and examined for clams. The clams were then measured and returned. The remainder of the sample was put into jars and preserved in 10 percent Formalin solution.

The spatial dispersion of Pismo clams at each of the locations was determined by a chi-square test of the variance to mean ratio (see App.) (E11iott, 1971). Small (less than 39 millimeters) and large (greater than 39 millimeters) clams were separated by length for comparison and testing dispersion because of different sized sampling units.

\section{Results.}

The intertidal and subtidal population densities, mean densities, and 95 percent confidence limits (C.L.) are given in Table 1. The mean densities at each location were tested between 1972 and 1973 for significant deviation by one-way analysis of variance (Woolf, 1968). No significant differences in mean density were found at any of the locations; however, in all cases subtidal densities were lower than intertidal densities. Moss Landing had the largest subtidal population with a density of $0.4 \mathrm{clams}$ per square meter. The greater intertidal densities were at Monterey Bay Academy and Sunset State Beach. Densities decreased north and south of these beaches. A single juvenile clam was found at Santa Cruz; no clams were found south of the Salinas River which includes Marina Beach and the beaches at Fort Ord and Monterey. The densities at the different locations were tested for significant deviations by using a Student-Newman-Keuls multiple range test (see App.) (Woolf, 1968). The results are given in Table 2. Density of small and large clams was greater at Monterey Bay Academy in both years. Density of small and large clams at Sunset State Beach in 1972 and 1973 was next highest. Clams were also surveyed on 13 December 1973, at Pismo Beach, California, for comparison with densities in Monterey Bay. The mean density of large clams at Pismo Beach was 0.7 clams per square meter (95 percent C.L. \pm 0.46). This was similar to the 1973 densities at Rio del Mar, Moss Larding, or Zmudowski State Beach (Probability, $\mathrm{P}=1$ ess than 0.01), but significant1y less than the densities at Sunset State Beach and Monterey Bay Academy. The mean density of small clams at Pismo Beach was one clam per square meter (95 percent C.L.), which was similar to the 1973 densities at Monterey Bay Academy or Zmudowski State Beach $(\mathrm{P}=$ less than 0.01), but significantly higher than the densities at Moss Landing, Sunset State Beach, and Rio del Mar.

The size-frequency structure of the clam population is given in Figure 2. Small clams 10 to 35 millimeters long were abundant only at Monterey Bay Academy and Sunset State Beach in the summer of 1972, and 
Table 1. Intertida1-subtidal densities of Pismo clams in Monterey Bay. Location Total No. Mean No.

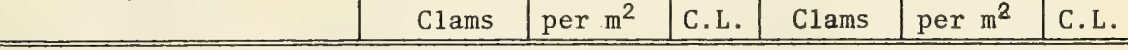

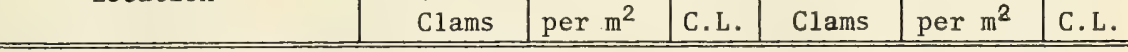
C.L. Total No. Mean No. $95 \%$ Intertidal density of $\mathrm{clams} / \mathrm{m}^{2}$ plus or minus $95 \%$ confidence limits

Santa Cruz

Rio del Mar

Monterey Bay Academy

Sunset State Beach

Zmudowski State Beach

Moss Landing

Salinas River Mouth

Marina Beach

Fort Ord

Monterey

\begin{tabular}{|r|l|l|r|l|l}
\hline \multicolumn{3}{|c|}{1972} & \multicolumn{3}{|c}{1973} \\
\hline 1 & 0.05 & 0.41 & 0 & 0.0 & 0.0 \\
28 & 1.4 & 0.88 & 28 & 1.40 & 0.83 \\
169 & 8.45 & 2.97 & 133 & 6.65 & 2.28 \\
117 & 5.85 & 1.76 & 71 & 3.55 & 1.45 \\
24 & 1.2 & 0.56 & 44 & 2.20 & 1.33 \\
14 & 0.7 & 0.35 & 16 & 0.80 & 0.69 \\
4 & 0.2 & 0.13 & 0 & 0.0 & 0.0 \\
0 & 0.0 & 0.0 & 0 & 0.0 & 0.0 \\
0 & 0.0 & 0.0 & 0 & 0.0 & 0.0 \\
0 & 0.0 & 0.0 & 0 & 0.0 & 0.0 \\
\hline
\end{tabular}

Subtidal density in clams $/ \mathrm{m}^{2}$ plus or minus $95 \%$ confidence limits

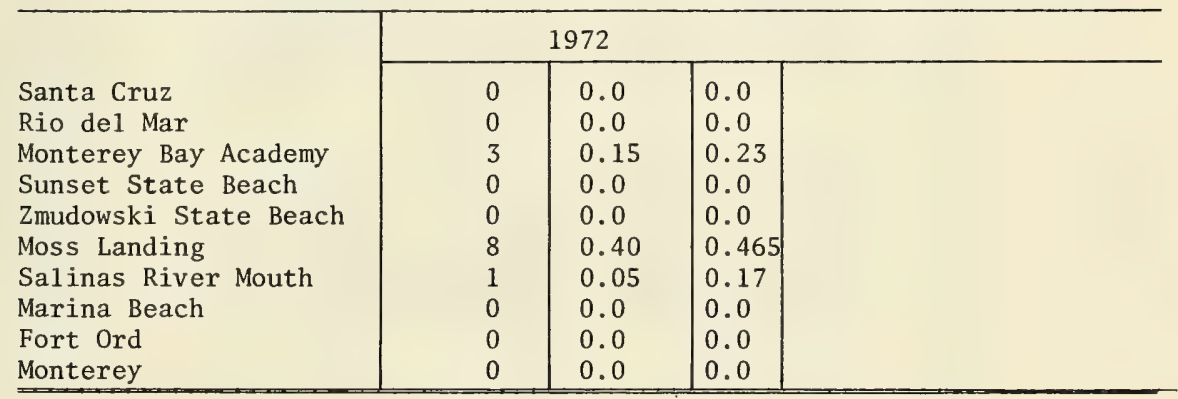




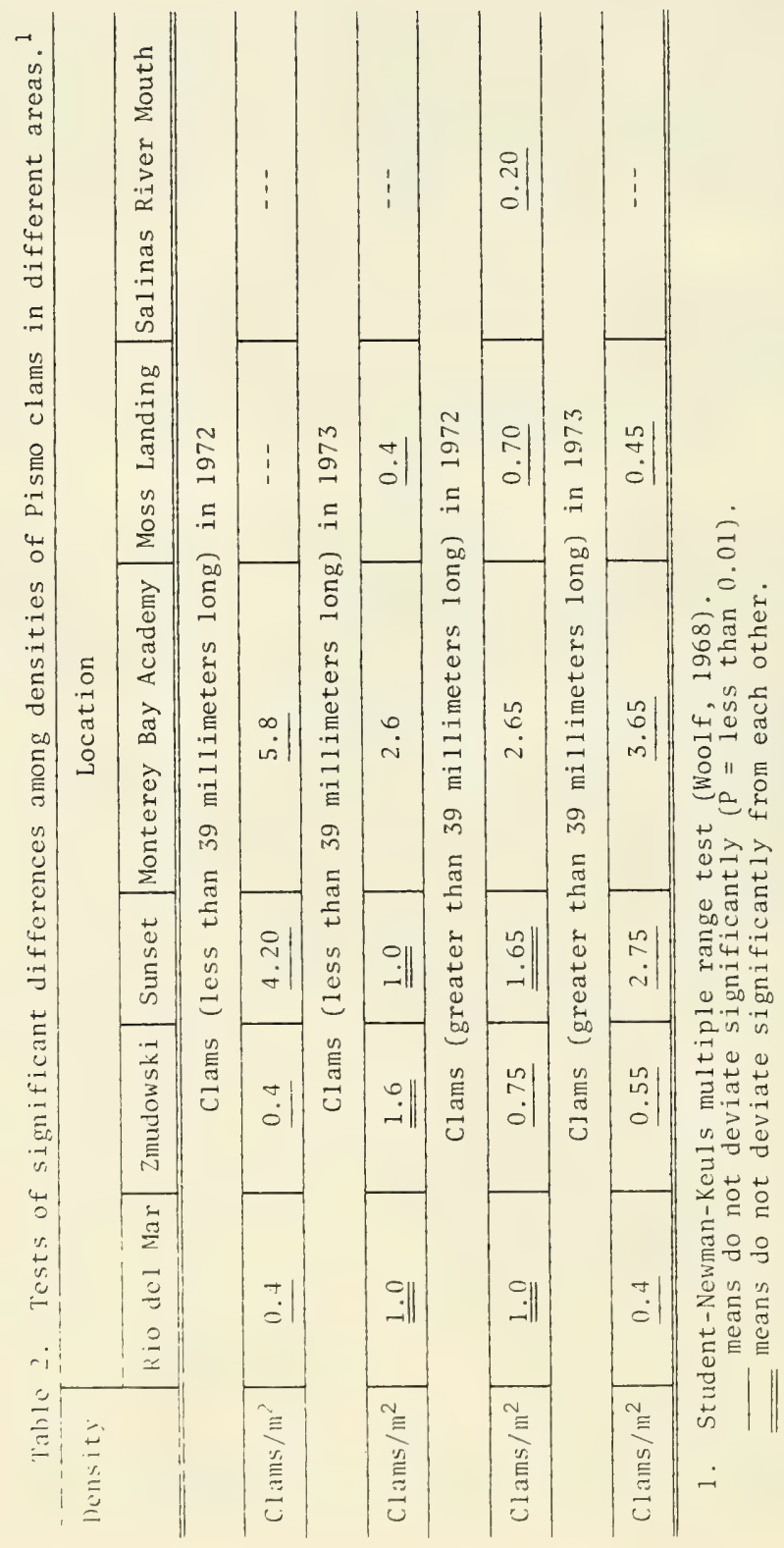



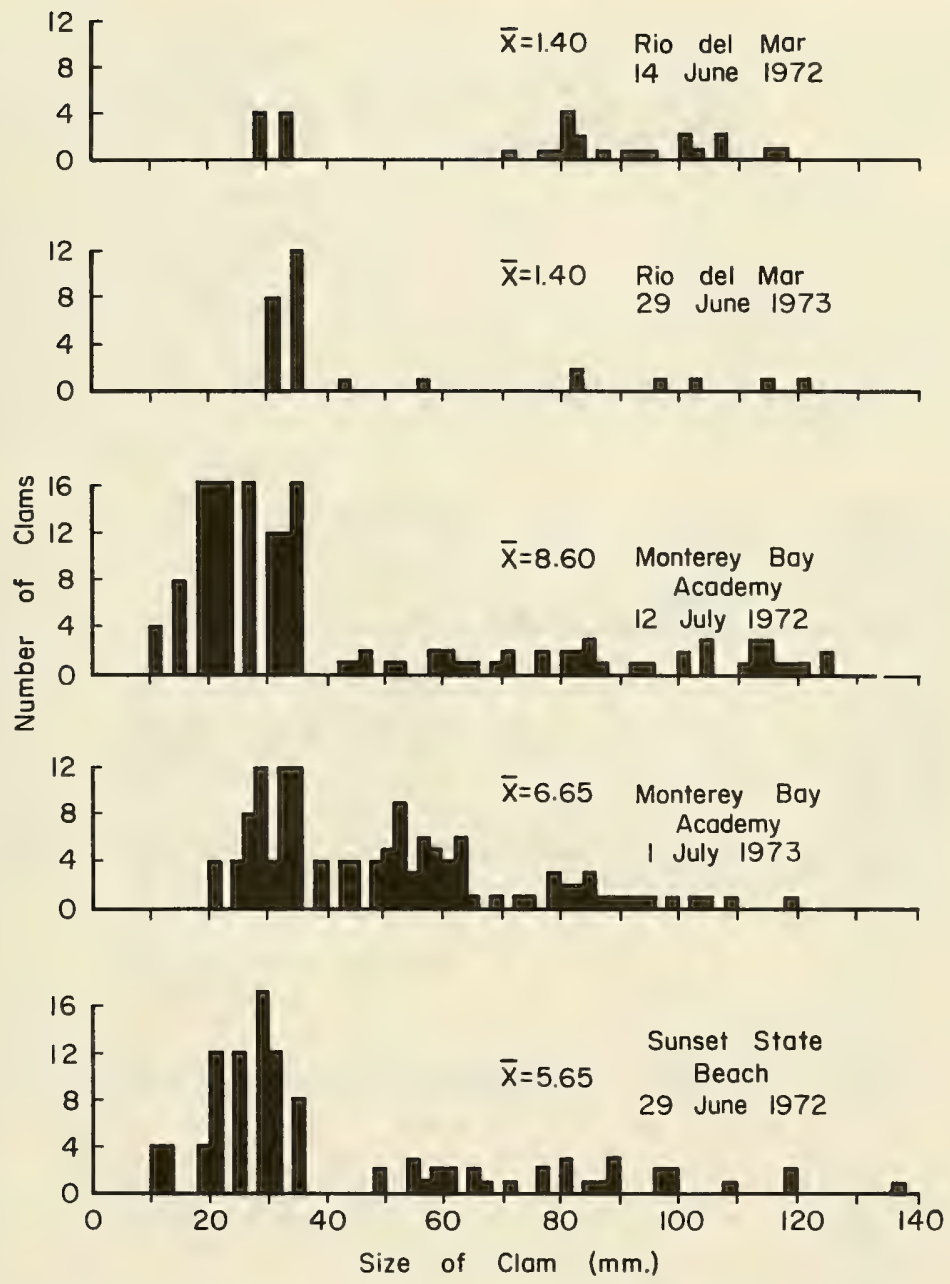

Figure 2. Size-frequency distribution of Pismo clams at selected beaches, 1972 and 1973 . 

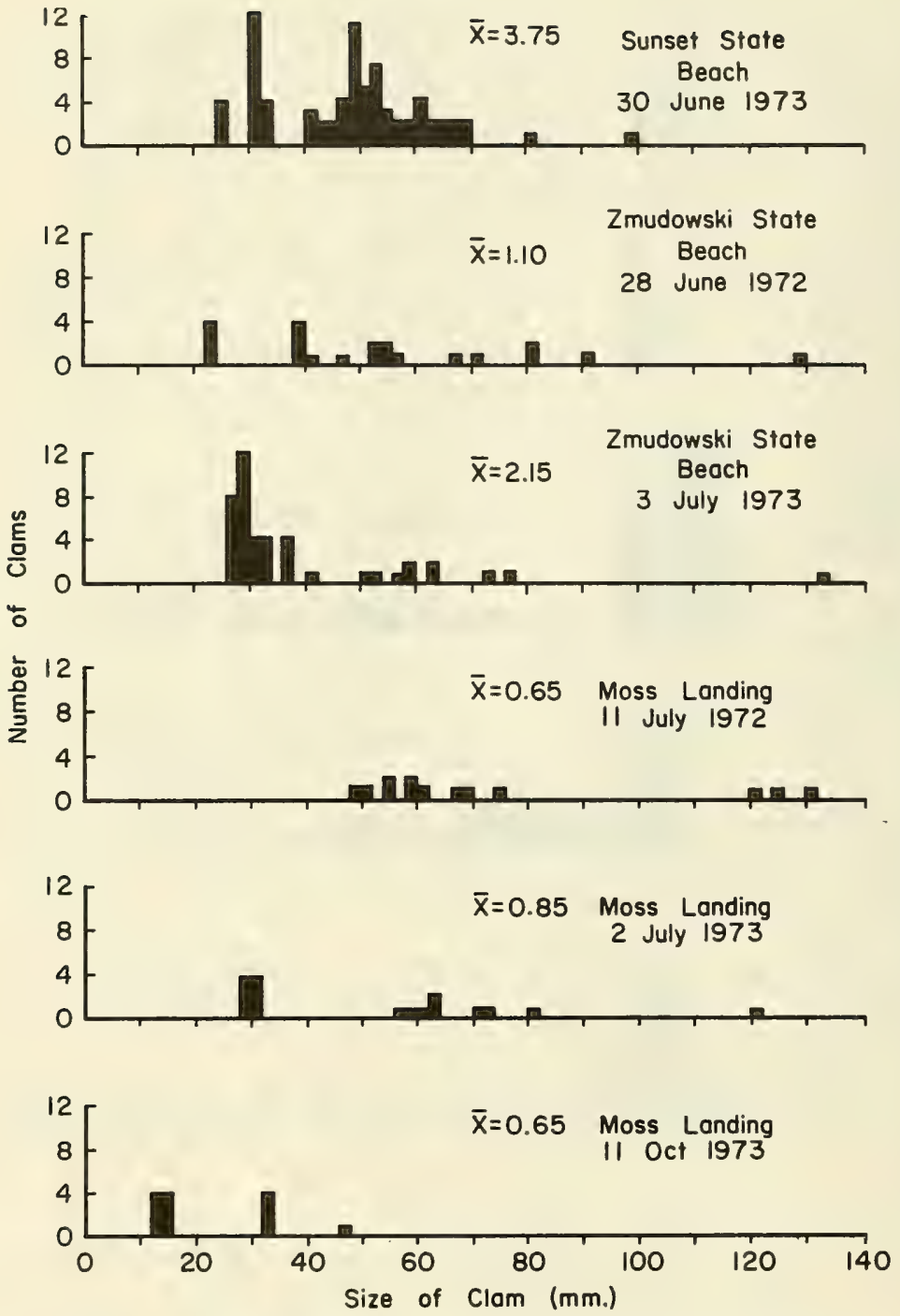

Figure 2. Size-frequency distribution of Pismo clams at selected beaches, 1972 and 1973-continued. 
in 1973 probably comprised the 40- to 70-millimeter-size classes. Most of these clams were probably spawned during the summer of 1970 . The number of juvenile clams 10 to 35 millimeters long on these two beaches was significantly less in 1973 than 1972, suggesting a poor year for survival (Mann-Whitney $U$ test (see App.), $P=<0.05$ ).

In testing the vertical distribution of clams, seven intertidal heights ranging from the -0.2- to 3.4-foot tidal level were sampled at Monterey Bay Academy to determine if clams were more abundant at different tide levels. The results (Fig. 3) showed no clams above the 2.6-foot level. Densities of clams from levels -0.2 to 2.6 feet were tested for significant differences with the Student-Newman-Keuls multiple range test (Woolf, 1968). There was no significant deviation in densities among levels which indicated very little change in densities within the vertical range.

Results of the spatial dispersion studies are given in Table 3 . All clams less than 39 millimeters long and most clams more than 39 millimeters long were randomly dispersed except for an apparently contagious dispersion of clams from Rio del Mar in 1972 and Monterey Bay Academy in 1973, and a regular dispersion of clams from Moss Landing in 1972. The test used in the analysis of the variance-mean ratio is only used effectively as a comparative index of dispersion when the means and number of clams for each sample are similar (E1liott, 1971). Since the means and number of clams were not similar in this test, comparisons could not be made among the various beaches; the degree of clumping in the samples which showed contagious dispersion patterns could not be determined. Most of the clams were randomly dispersed, and in a few instances where this was not the case, additional data to test the significance or degree of departure from randomness were not available.

\section{Discussion.}

During the study period, Pismo clams in Monterey Bay occurred between the Salinas River and Rio del Mar with the heaviest concentrations at Sunset State Beach and Monterey Bay Academy. No clams were found south of the Salinas River, and only one clam was found at Santa Cruz. The aerial survey of Monterey Bay conducted in 1969, by the California Department of Fish and Game (DahIstrom, 1973, personal communication) showed a similar distribution of clammers. Most of the clammers were concentrated near beaches where the highest densities of clams were recorded during the study period. No clammers were found at Santa Cruz or south of the Salinas River.

Surprisingly, the density of large Pismo clams south of Monterey Bay at Pismo Beach, known among sports fishermen for its large clam population, was significantly lower than at Sunset State Beach and Monterey Bay Academy. During the years of commercial clamming, more than 10 times as many Pismo clams were harvested at Pismo Beach as in Monterey Bay (Herrington, 1930). The reason for the lower density of Pismo Beach is 


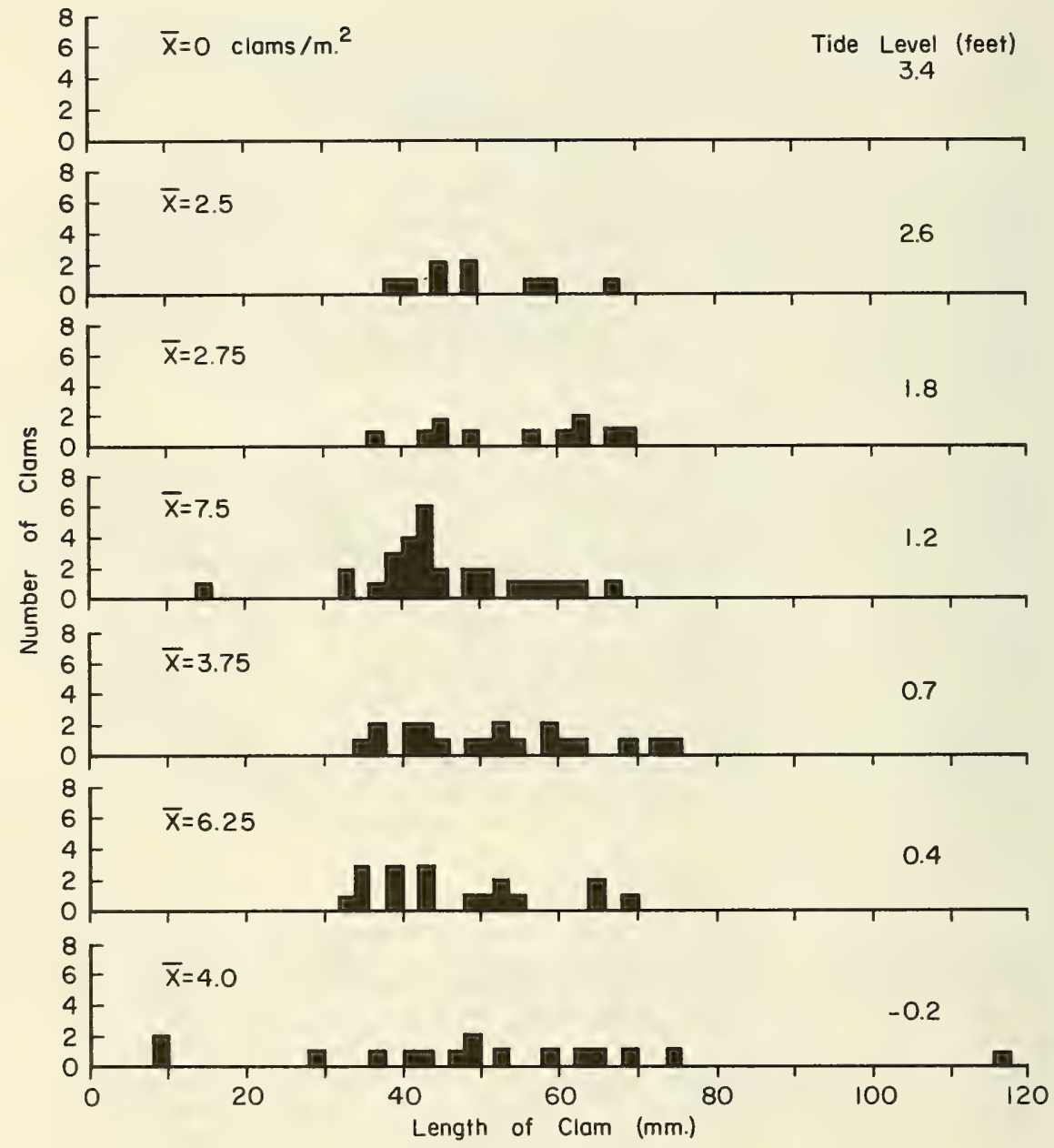

Figure 3. Vertical distribution of clams at Monterey Bay Academy. 


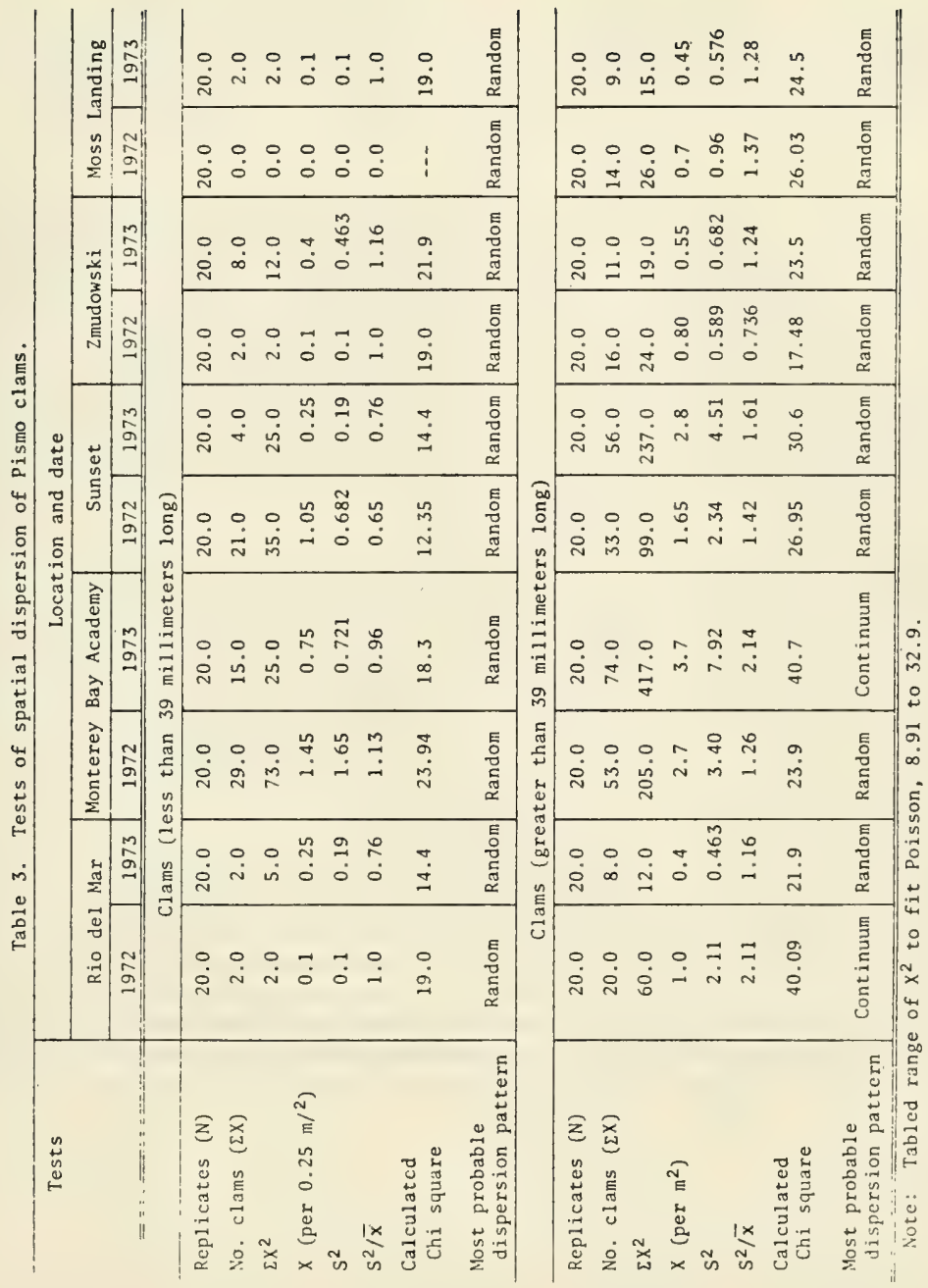


not known, but it is believed to be the result of heavy fishing. It is also possible enough samples were not taken to adequately estimate the density. Although density is lower at Pismo Beach, the number of clams available to clanners may be greater due to a larger surface exposure during low tides. This area is a result of a flatter beach slope at Pismo Beach in comparison to the beaches of Monterey Bay.

Large populations of subtidal Pismo clams were not found in Monterey Bay as reported by Fitch (1965) at Zuma Beach in southern California. The highest density, 0.4 clams per square meter, was found at Moss Landing which is considerably lower than the six clams per square meter found by Fitch (1965) at Zuma Beach. Diving observations during the clam collection for the reproductive study suggested the density at Moss Landing may have been higher than 0.4 clams per square meter. As many as six clams were frequently collected from an area of approximately 1 square meter. Large numbers of subtidal clams were also found at Pismo Beach where 20 clams were collected on one occasion out of an area estimated to be smaller than 2 square meters.

Densities of Pismo clams did not deviate significantly at seven different intertidal heights; however, the different levels were only sampled on one beach. Weymouth (1923) and Baxter (1961) reported that 1 -year-old Pismo clams were mainly found in the middle part of the intertidal range; the tide level at the middle part of the tidal range was not reported. During this survey, very few clams of that age (10 to 39 millimeters long) were found at any tide level (Fig. 3). But this could be an artifact of sampling only one beach. No clams were found above the 2.6-foot tidal leve1 in Monterey Bay.

In most areas surveyed Pismo clams were randomly dispersed. This type of dispersion has also been found in other bivalves, i.e., Scrobicularia plana (Hughes, 1970), Mulina Zateralis (Jackson, 1968), Gemma gemma (Jackson, 1968), Cardium edule (Kosler, 1968), and Macoma baltica (Kosler, 1968). Large Pismo clams and other bivalves regularly dispersed have been reported in other studies. Tellina tenuis, for example, is regularly dispersed in low densities and randomly dispersed in high densities (Holme, 1950); Mya arenaria shows a clumped dispersion pattern (Gaucher, 1965).

5. Conclusions.

The highest intertidal densities of Pismo clams in Monterey Bay were found at Monterey Bay Academy and Sunset State Beach. Densities decreased to the north and to the south of these beaches. No clams were found south of the Salinas River; only one juvenile clam was found at Santa Cruz at the north end of the bay. The density of large clams south of the bay at Pismo Beach was significantly less than densities at Monterey Bay Academy or Sunset State Beach. The mean densities of Pismo clams at seven intertidal heights did not differ significantly indicating there was no vertical preference. In most of the surveys the clams were 
randomly dispersed. Subtidal clams were few and occurred at a maximum density of 0.4 clams per square meter $(95$ percent C.L. $=0.465$ ) at Moss Landing.

\section{SEDIMENT STUDIES}

1. Introduction.

There are no previous studies that relate sediment parameters to distribution patterns of Pismo clams, but a few studies exist for other species of bivalves. Maurer (1969) reported that the distribution and abundance of most species of bivalves at Tomales Bay in western California are strongly influenced by sediment type. Dunhill and Ellis (1969) suggested sediment type may play an important role in regulating the distribution of Macoma along Victoria, British Columbia. Pratt and Campbel1 (1956) found the growth of the quahog Mercenaria mercenaria was curbed in sediments with a high silt-clay content. Swan (1952) observed that the growth of the clam, Mya arenaria, may be strongly affected by the type of substrate. The clams grew about twice as fast in sand as in a compact mud-gravel-shel1 mixture. Sediment parameters play a strong regulatory influence on the distribution and abundance of certain clams. In this study, certain sediment parameters were correlated with the presence and abundance of Pismo clams.

2. Methods and Materials.

Fjve sediment cores were taken at each site from 1-square-meter quadrats which were randomly selected within the 60 - by 80 -foot grid system. Cores 3.5 centimeters in diameter were taken with a plastic corer, 56 centimeters 1ong. Sediments were analyzed by the Emery tube method (Emery, 1938) because it is a better measurement of the "hydraulic" size value for particles of unusual shape, density, or porosity (Folk, 1966). Since beach and intertidal sediments are under the influence of the marine environment, sediment parameters are best described by hydraulic properties. Sediments were analyzed for mean grain size, sorting, skewness, and kurtosis, using equations by Folk and Ward (1957).

Beach profiles were obtained for some beaches by sighting the horizon (Emery, 1961).

\section{Results.}

Sediment parameters were analyzed to determine if there was a relation of sediment type to the distribution of Pismo clams. Because clams, particularly juveniles, are not found deep in the sand, only the top 2 inches of the sediment cores were analyzed.

An analysis was made to determine if there was a difference in the mean grain size of sand between beaches with and without clams. Because the kurtosis estimates were not within the limits of a normal distribution 
(Folk and Ward, 1957), a nonparametric Mann-Whitney U test was used to compare mean grain sizes and sorting coefficients. There was a significant difference in mean grain size between beaches with clams and beaches without clams $(P=0.05)$. Beaches with clams had sand of a smaller grain size. There was no significant difference in the sorting coefficient between beaches with and without clams.

Tests were made to determine if there was a correlation between clam abundance and grain-size. Samples from all stations were combined to obtain a large enough sample, and a nonparametric Spearman rank correlation test was used because the distribution of clams was not always normal. Correlation tests were performed between clams less than 39 millimeters long, greater than 39 millimeters long, and all sizes versus mean grain size. Tests were also made to determine correlation between number of clams and sorting coefficient sand. The correlation coefficients $\left(\mathrm{r}_{s}\right)$ are listed in Table 4 . There was no significant correlation between numbers of clams and mean grain size $(P=$ greater than 0.05$)$, but a significant correlation $(P=1$ ess than 0.05$)$ was found between all sizes of clams versus mean grain size, clams less than 39 millimeters, and the sorting coefficient. There was no significant correlation between clams greater than 39 millimeters and the sorting coefficient.

Table 4. Correlation coefficients $\left(r_{S}\right)$ between clams and sediment parameters.

\begin{tabular}{|l|c|c|}
\hline Clam size & Mean grain size & Sorting coefficient \\
\hline \hline All sizes & 0.214 & $0.369^{1}$ \\
$<39 \mathrm{~mm}$ & 0.098 & $0.380^{1}$ \\
$>39 \mathrm{mn}$ & 0.260 & 0.133 \\
\hline
\end{tabular}

1. Significant at $\mathrm{P}<0.05$

(Table $\left.r_{s(0.05)}=0.336\right)$.

Slopes of beaches with clams and without clams are 1isted in Table 5 . An estimate of the slopes was derived by smoothing the profile from high water mark to the corrected 0.00 tide level. The Mann-Whitney $U$ test was used, and a significant difference was found between slopes from beaches with clams and without clams $(P=1$ ess than 0.05). Beaches without clams had a steeper slope than beaches with clams. Graphs of these beach profiles are presented in Figure 4.

4. Discussion.

A significant difference in mean grain size was found between beaches with and without clams. The grain size from beaches with clams was smaller $(0.25 \pm 0.09$ millimeters $)$ than beaches without clams $(0.50 \pm 0.3 \mathrm{milli}-$ meters). Slopes were significantly steeper for the beaches without clams. The relationship between beach slope and grain size is translated into 
Table 5. Beach profile slopes (foot per foot) of beaches with and without clams.

\begin{tabular}{l|c|c|c|c}
\hline \multirow{2}{*}{ Date } & \multicolumn{2}{|c}{ Beaches with clams } & \multicolumn{2}{c}{ Beaches without clams } \\
\cline { 2 - 5 } & Moss Landing & Manresa Beach & Marina Beach & Salinas River Mouth \\
\hline Aug. 1972 & 0.08 & 0.05 & 0.11 & 0.10 \\
Sept. 1972 & 0.06 & 0.04 & 0.13 & 0.08 \\
Oct. 1972 & 0.07 & 0.05 & 0.09 & 0.06 \\
Nov. 1972 & 0.06 & 0.04 & 0.11 & 0.09 \\
Dec. 1972 & 0.07 & 0.02 & 0.06 & 0.11 \\
Jan. 1973 & 0.05 & 0.04 & 0.10 & ---- \\
Feb. 1973 & ---- & ---- &.-- & 0.13 \\
Mar. 1973 & 0.05 & 0.04 & 0.10 & 0.09 \\
\hline \hline
\end{tabular}



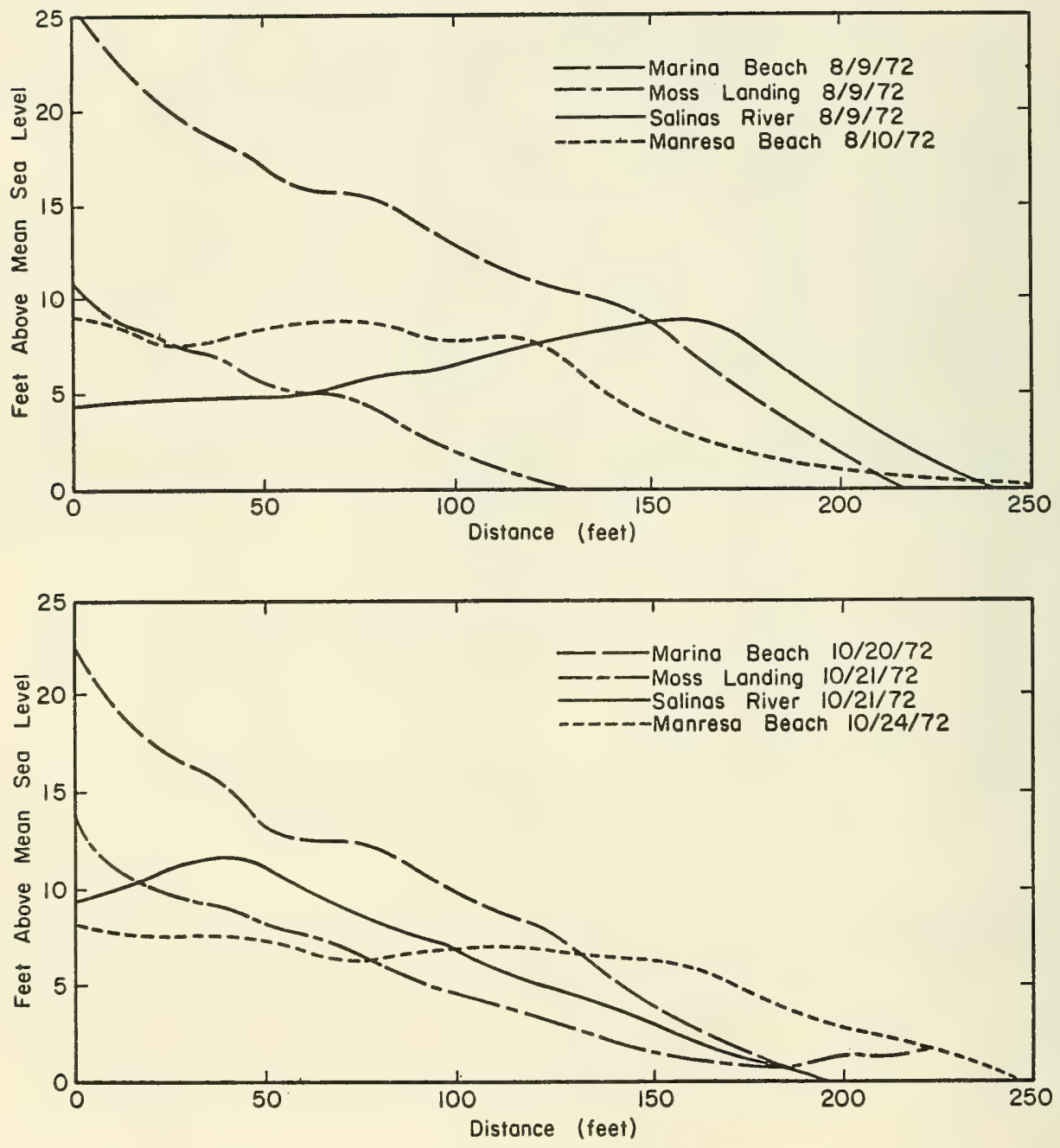

Figure 4. Profiles of beaches with and without clams. 

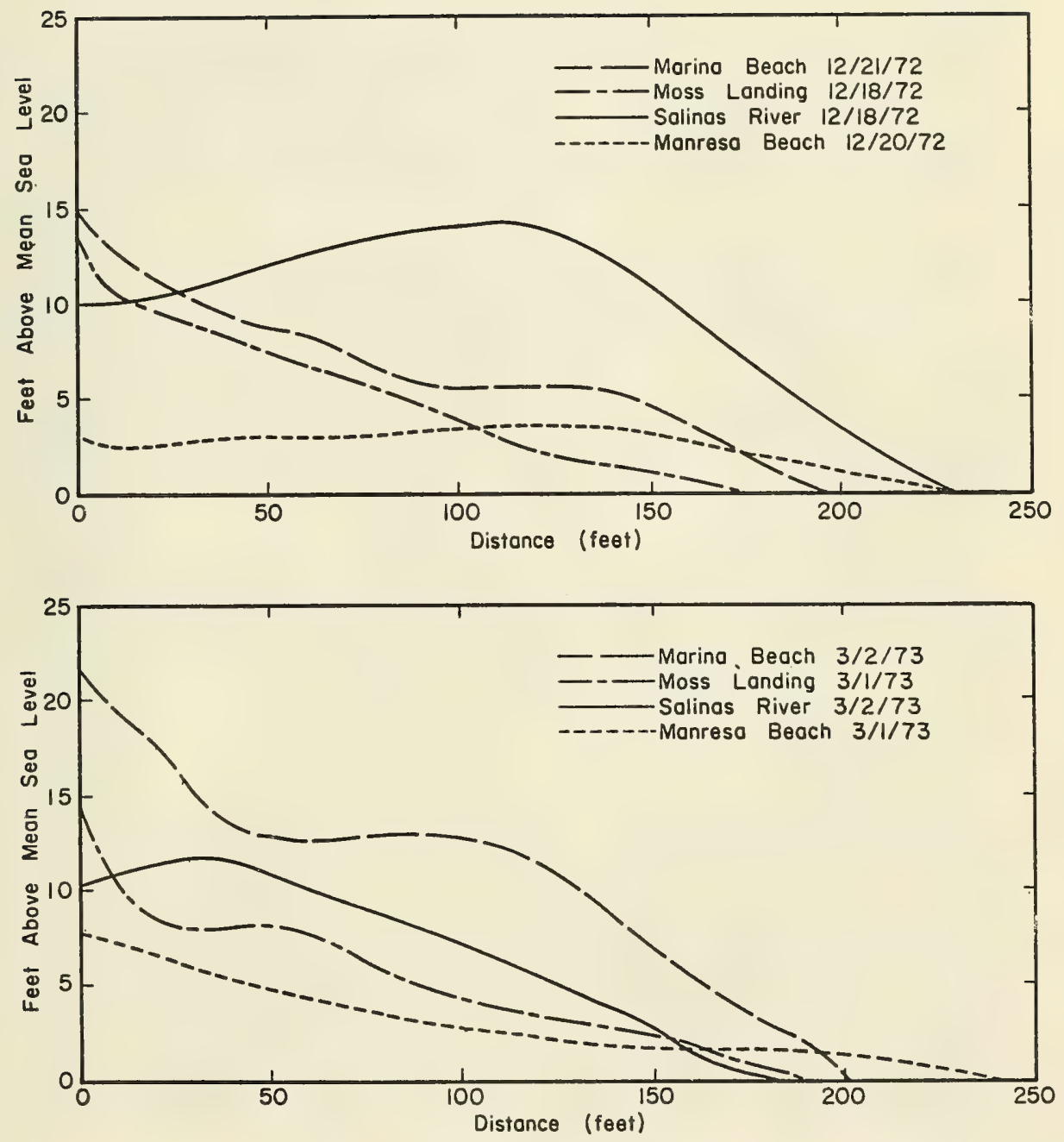

Figure 4. Profiles of beaches with and without clams-continued. 
available energy, indicating the kinetic energy (velocity) of the depositing agent (i.e., waves) (Sahu, 1964). Beaches with a steep slope and large mean grain size represent a high energy beach; beaches with a gentle slope and smaller mean grain size represent a low energy beach. Therefore, the beaches without clams may be characterized as high energy beaches, and beaches with clams as low energy beaches. This does not imply a cause and effect relationship because additional parameters affect Pismo clam distributions.

There was no significant difference in sorting coefficients between beaches with clams $(0.55 \pm 0.34)$ and beaches without clams $(0.50 \pm 0.28)$. The value of sediments ranged from well sorted to moderately sorted according to a verbal scale of sorting by Folk (1966). The higher the sorting coefficient, the poorer the sediment is sorted. Interestingly, there was significant correlation between the sorting coefficients and number of clams, with a higher number of clams associated with a higher sorting coefficient (Table 4). The highest correlation was found in the greater than 39-millimeter class range, which represented the first-year class of Pismo clams.

\section{Conclusions.}

There are correlations between grain size and slope of beaches with and without Pismo clams in Monterey Bay. Beaches with clams have a smaller grain size and beaches without clams have steeper slopes.

\section{SEA OTTER PREDATION ON PISMO CLAMS}

\section{Introduction.}

Sea otters (Enhydra Lutris) were rarely observed in the Moss Landing area before the spring of 1973. After the arrival of a substantial number of otters during the spring and summer of 1973, broken Pismo clamshells were found on the surface of the sand in both intertidal and subtidal zones. Since Pismo clamshells are thick and resistant to breakage by the surf, the increase in the number of broken clamshells was probably due to the sea otters. The following September, a feeding rate was taken for the sea otters observed feeding on Pismo clams at Moss Landing. Densities of Pismo clams in this area were obtained during the presence of the sea otters and after departure the following fall. The effect of sea otters on the clam population was then estimated by comparing these densities with the estimates of clam density taken in 1972 .

\section{Methods and Materials.}

The density of Pismo clams was determined by methods described in the preceding section. Observations of the sea otters feeding on Pismo clams were made during September 1973, using a Bausch and Lomb 15-60X zoom telescope. During each observation, the time and location of feeding, estimated size of clam, and prey item were recorded. 


\section{Results.}

The size-frequency distribution of Pismo clams at Moss Landing is shown in Figure 2 and the densities in Table 1. The mean densities of the clams smaller than 47 millimeters long obtained on 11 July 1972 , 7 July 1973, and 11 October 1973, were tested for deviation with a Student-Newman-Keuls multiple range test (Woolf, 1968). The mean densities did not deviate significantly. However, when clams larger than 47 millimeters were compared, there were substantial differences in densities in the three time periods. There were 13 clams larger than $47 \mathrm{millimeters} \mathrm{1ong} \mathrm{recorded} \mathrm{on} 11 \mathrm{July} 1972,9$ on 1 July 1973, and none on 11 October 1973. Forty additional square-meter quadrats were sampled at Moss Landing on 10 December 1973, and no Pismo clams larger than $47 \mathrm{millimeters} \mathrm{long} \mathrm{were} \mathrm{found.}$

Further evidence of the decline of Pismo clams coincidental with the appearance of feeding sea otters became available from the catch-per-unit effort observations in collecting clams for gonad studies. Most collections before April 1973 were made within 15 minutes at Moss Landing with two divers collecting 20 subtidal clams within 45 minutes. Clams became progressively more difficult to obtain by the summer of 1973 . By September, divers with 7 hours bottom time had obtained only one clam. Also, the sand bottom contained a large number of broken she11s; before April 1973 broken shel1s were rarely observed.

Clammers were interviewed during November and December 1973 and January 1974 to determine their success in obtaining legal-sized clams (larger than 126 millimeters long). Eleven clammers at Moss Landing dug 13 workdays after the season opened in October and caught only one legal-size clam. The same 11 clammers took 137 legal-size clams in 12 workdays the previous season. All the clammers interviewed stated that the clamming was the worst experienced at Moss Landing and some of the clammers had been clamming there for 20 years.

Several direct observations were made of sea otters feedings on Pismo clams. On one occasion a single otter ate 24 Pismo clams and two mole crabs (Blepharipoda occidentalis). The average estimated size of the clams consumed was 101 millimeters and the otter fed for 2 hours, 15 minutes. On another occasion an otter fed on 14 Pismo clams and 37 mole crabs. The average size of the clams was estimated at 127 millimeters and the feeding period at 4 hours. The California Department of Fish and Game observed one otter consuming 22 Pismo clams in 3 hours, 45 minutes at Atascadero State Beach (Paul Wilde, 1973, personal communication).

The density of otters varied at Moss Landing. At one time 10 otters were observed, but the number declined to 1 after 24 September 1973.

4. Discussion.

The interviews and estimated clam densities obtained by the catch-perunit effort indicate a recent decline in the density of large clams at 
Moss Landing. Observations of sea otters feeding on Pismo clams and the increase of broken clamshells on the beach strongly suggest the sea otters are the principal cause of the decline.

Fortunately, there are still small clams at Moss Landing. In the past there have been enough clams for Moss Landing to be the mainstay of a commercial fishery for Pismo clams in Monterey Bay (Herrington, 1930). Whether the population will return to prior levels will depend upon the satisfactory recruitment in future years from clam populations not depleted by the sea otters.

Although the density of Pismo clams has declined at Moss Landing, the lowered density may be the more natural density. Before man exterminated the sea otter from Monterey Bay and the early commercial fishing began, the otters may have fed upon Pismo clams with regularity, keeping the density at a lower level.

\section{Conclusion.}

During the spring and summer of 1973 sea otters feeding on Pismo clams were observed at Moss Landing, California. Densities of Pismo clams before the sea otter's arrival at Moss Landing and after their departure, catch-per-unit effort data in the collections of clams for reproduction study, and clammer interview data all indicate a decrease in the density of large Pismo clams at Moss Landing. Direct observations of the sea otters feeding on Pismo clams and the increase in broken clamshells on the beach suggest that sea otters were the principal cause of the decrease.

\section{REPRODUCTIVE CYCLE}

\section{Introduction.}

Previous studies on the reproduction of Pismo clams covered southern California and several locations in Baja, California (Mexico) (Coe, 1947; Coe and Fitch, 1950). These studies suggest the reproductive cycle in Pismo clams is extended in the southern part of its range and somewhat restricted in the northern part. A restricted spawning season in the northern part of an animal's range, which is not uncommon in many intertidal animals (Giese, 1959), has also been found in the bivalves Mya arenaria (Ropes and Stickney, 1965) and Mercenaria mercenaria (Porter, 1964). Since Monterey Bay is near the northern limit of the Pismo clam's range, there was concern that spawning would only occur during the warmest years or would not occur at a11 and the clams would depend on the recruitment of larvae from more southerly populations. Previous information concerning the reproductive cycle in Monterey Bay (Giese, et al., 1967) showed the weight of the gonad increased during the spring, reached a maximum from June to September, and then rapid1y decreased. No evidence was presented to show whether the clams spawned their gametes or resorbed them. The spawning of subtidal populations of clams which were found in large numbers at Zuma Beach (Fitch, 1965), Pismo Beach, and 
Moss Landing were also of interest. If these populations are the major source of gametes, keeping them at the present level could prove essential in providing recruitment for the heavily clammed intertidal area.

2. Methods and Materials.

About 17 to $20 \mathrm{clams}$ were collected each month from four locations to determine the degree of gonadal maturity. Clams were collected in the intertidal zones near the north end of Manresa Beach from November 1971 to October 1973, and Moss Landing from February 1972 to October 1973, and the subtidal zones at Moss Landing from February 1972 to September 1973, and Pismo Beach from June to October 1973. The clams were then taken to the laboratory and either processed immediately or put into running seawater and processed within 48 hours. In processing, the clam was removed from the she1l and preserved in Formalin. A small block of tissue that included the gonad was later cut from the base of the foot, washed overnight in water, dehydrated with alcohol, saturated with paraffin, and poured into a mold. The mold was sliced into sections, 7 micrometers thick, which were stained with eosin and haemotoxlyn and mounted on slides. The tissues were then examined ard separated by the stage of gonadal maturity, using a classification modified by Ropes and Stickney (1965). The classification called the gonad inactive if the follicle was collapsed with no gametes (Fig. 5), early active if small oocytes had begun forming on the follicle walls (Fig. 6), Zate active if oocytes were rounded with well-developed nuclei and attached to the follicle walls (Fig. 7), mature or ripe if most oocytes were well developed and lying free within the follicle (Fig. 8), partly spent if the follicle was partially empty of mature oocytes (Fig. 9), and spent if the follicle was empty with the exception of residual oocytes (Fig. 10). Male gonads were not classified because of the extreme difficulty in recognizing the various maturation stages of the testes packed with deeply staining spermatozoa that obscured all detail.

\section{Results.}

a. Stages of Gonad Maturity. Examination of the histological preparations of gonad tissue showed that female Pismo clams in Monterey Bay were in the early active stage from December to July (dominant from January to March, Table 6 and Fig. 11) and the late active stage from March to June (dominant in April and May, Fig. 12). The clams attained each stage about 1 month earlier in 1973 than 1972. Intertidal clams at Manresa Beach reached each stage 1 month earlier than intertidal clams at Moss Landing. Subtidal clams at Moss Landing remained in each stage 1 month later.

The ripe stage of the clams was from May to September (Fig. 13). Intertidal clams reached this state at Moss Landing 1 month later in 1973 than in 1972, and at Manresa in May of both years. Subtidal clams at Moss Landing reached this stage 1 month later than intertidal clams from Moss Landing or Manresa Beach. Intertidal clams at Manresa and subtidal 


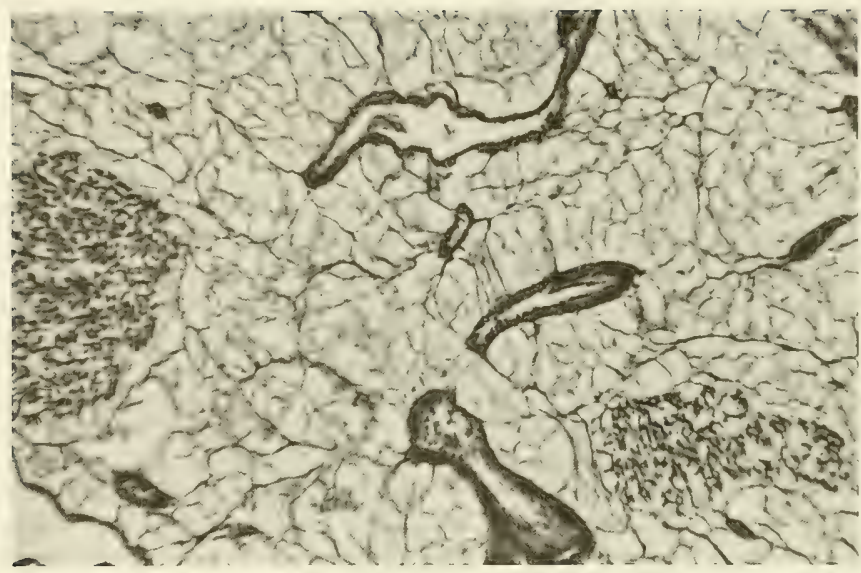

Figure 5. Female gonad in the inactive stage (40X magnification).

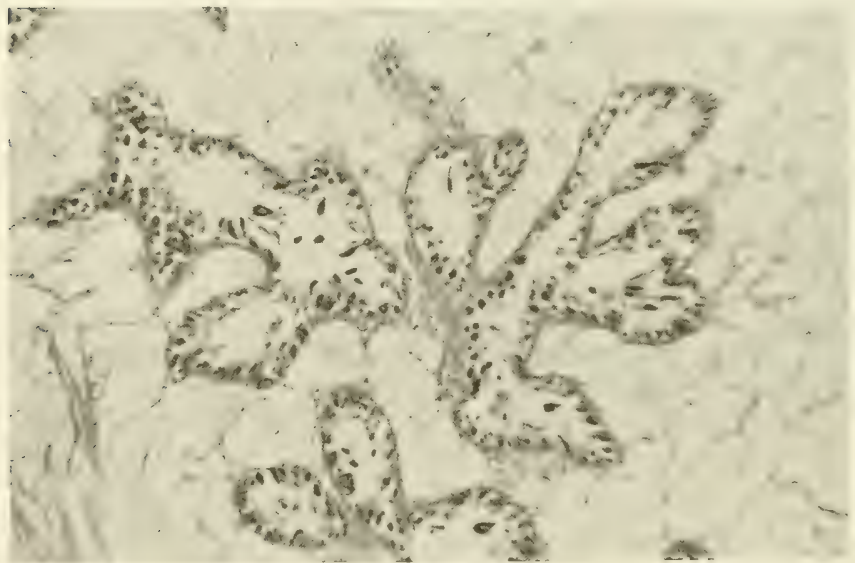

Figure 6. Female gonad in the early acotive stage (40X magnification). 


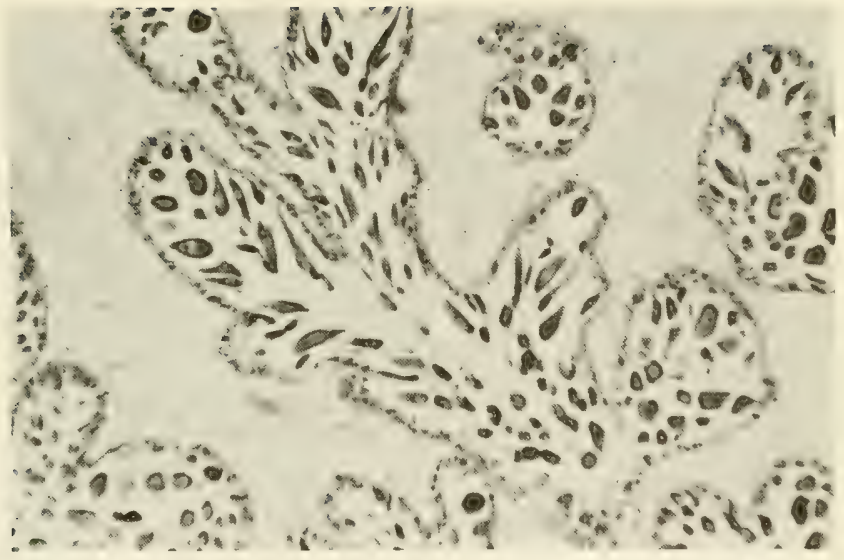

Figure 7. Female gonad in the late active stage (40X magnification).

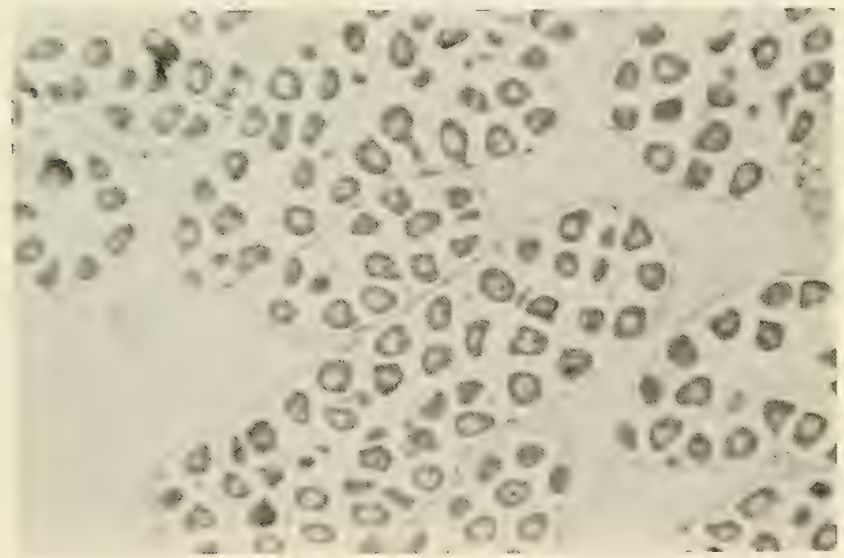

Figure 8. Female gonad in the ripe or mature stage (40X magnification). 


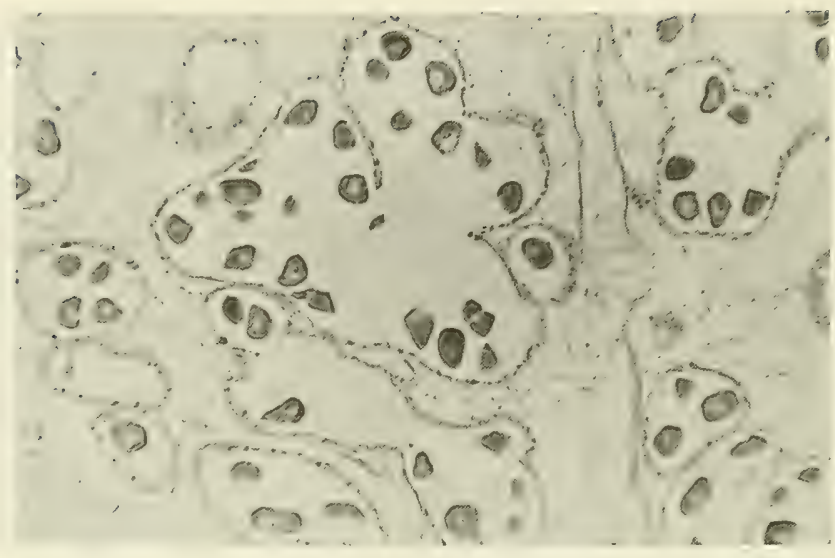

Figure 9. Female gonad in the partly spent stage (40X magnification).

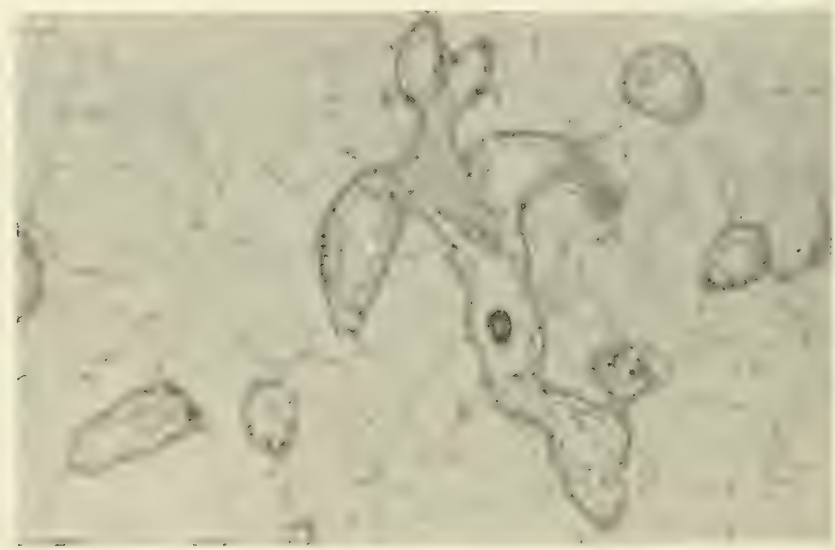

Figure 10. Female gonad in the spent stage (40X magnification). 


\begin{tabular}{|c|c|c|c|c|c|c|c|c|}
\hline & แัّ & m: : :mAn \& & & $:::: \ln N=\infty$ & & $::: i:: i \quad i$ & & $: 1: 1709$ 요 \\
\hline & 茖 & $:: 1-\simeq:^{-}$\& & & $:::: m-\infty \quad 8$ & & $::_{i n-i}=-$ & & $:: 1-\infty-\infty \quad 9$ \\
\hline & 定 & $1: 1 \operatorname{son}:=8$ & & $i: m \infty: z \therefore$ & & $::: m: \simeq 9$ & & $: 1:-\infty: \approx$ 요 \\
\hline & त्रे & $i: i^{n-1}:=8$ & & $: 1: n-\geq 8$ & & $::: n n: m 8$ & & $: 1: 0 n i^{\circ}$ i \\
\hline & 2. & $i i^{-n}:^{\sigma} \infty$ & & $i: \ln ^{\infty}: \infty$ & & imo-i: & & $:-10-1=9$ \\
\hline & $\rightarrow$ & $i i^{N N}:: 99$ & & $1+\sigma N-\geq 8$ & & Na: $:=\infty$ i & & $:: \vdots:::::: \vdots$ \\
\hline & $\dot{H}$ & Non: : in & & $\neg m-1: 1: m 8$ & & No: : : : & & $::::::::$ : \\
\hline & 8 & $\sim a::: a^{a}$ 尺 & & $\approx 0::::^{m}$ i & & 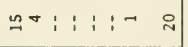 & & $i:::::: \quad:$ \\
\hline & \begin{tabular}{|l|}
0 \\
0 \\
0
\end{tabular} & $\pm m::: 1:=$ & & $\Rightarrow: 1:: I^{n N}$ i & & $\varkappa^{n}:: i: m: a$ & & $:::: 1::: 1:$ \\
\hline & $\dot{\mathrm{m}}$ & 유:1:1: $1: 1: 8$ & & m: : : : & & $\infty: 1:: 1^{n}:$ o & & $::::::: \quad$ : \\
\hline & & : $:$ : :HNA O & $\Rightarrow$ & I:: : : : Un o & $\rightarrow$ & $=:: 1:-\rightarrow \quad 9$ & $\frac{\pi}{4}$ & $:: 1:: \vdots::: \quad:$ \\
\hline & : & $m:$ : : Non & $\overrightarrow{5}$ & I: $::$ - $m$ m & $\overrightarrow{7}$ & $\infty:: 1:$ : & 总 & $:::::::$ : \\
\hline & نة & $m:: 1::^{\circ}=8$ & 点 & mi: inon o & $\infty$ & $N: \begin{array}{l:ll}n & -N \infty & 9\end{array}$ & $\frac{5}{5}$ & $:::::::$ : \\
\hline & 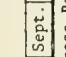 & $i$ inntin & 㺃 & i: isonen & 足 & 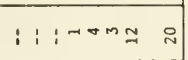 & $\begin{array}{l} \\
\\
0 \\
0 \\
\end{array}$ & $:::: 1::: 1::$ \\
\hline & 表: & : $11^{\circ}$ on:a & $\frac{n}{2}$ & $1: 10^{N}: \infty$ ㅇ & $\frac{0}{2}$ & $:$ NDNAm & 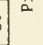 & $::::::::$ : \\
\hline & $\approx$ & $i::^{\infty}:^{n} \stackrel{\infty}{\sim}$ & & i: $: N M: \cong \stackrel{\infty}{\sim}$ & & : : i: :णnd & & $::::::: 1$ \\
\hline & 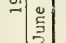 & $:: i n::$ : & & $:: 1: i^{\text {n }}$ i & & : : & & $:::::: 1:$ : \\
\hline & 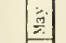 & 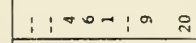 & & iman $: i^{0}$ 요 & & $: \infty-1:: \geq \infty$ & & $:::: 1:: 1:$ \\
\hline & $\dot{a}$ & $: i^{\sigma}: 1: 0$ & & $i^{\sigma n:}:: \pm 8$ & & No: : ma i & & $:: 1:: 1:: 1: \vdots$ \\
\hline & $\dot{s}$ & $\rightarrow 0 N:$ :- & & $+\infty: 1: t^{\infty} \Omega$ & & $\infty: i: n n \quad \infty$ & & $::::::: \vdots:$ \\
\hline & : & NN: : : : & & $\stackrel{0}{\circ}: 1:-\infty \Omega$ & & $z^{N}:::^{N m} \infty$ & & 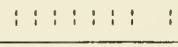 \\
\hline & \begin{tabular}{|c|}
$\dot{5}$ \\
\\
\end{tabular} & 으: : 1ーnm & & $:: 1:: 1::$ & & 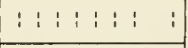 & & $:: 1: 1: 1: 1: 1:$ : \\
\hline & - & $\pm \sim: i i^{+\infty}$ & & $:: 1:: 1: 1: 28$ & & $::: 1::::: \quad:$ & & $:::::::: 1:$ \\
\hline & $\therefore$ & $\infty::::^{\infty}$ i & & $:: 1: 1: i:$ \& & & $:: i: i:: i \quad i$ & & $:: 1: i: i: i$ \\
\hline 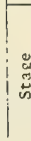 & & 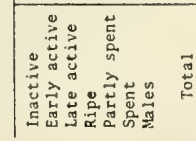 & & 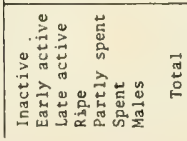 & & 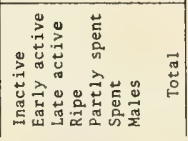 & & 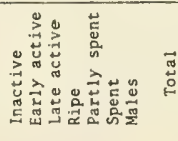 \\
\hline
\end{tabular}




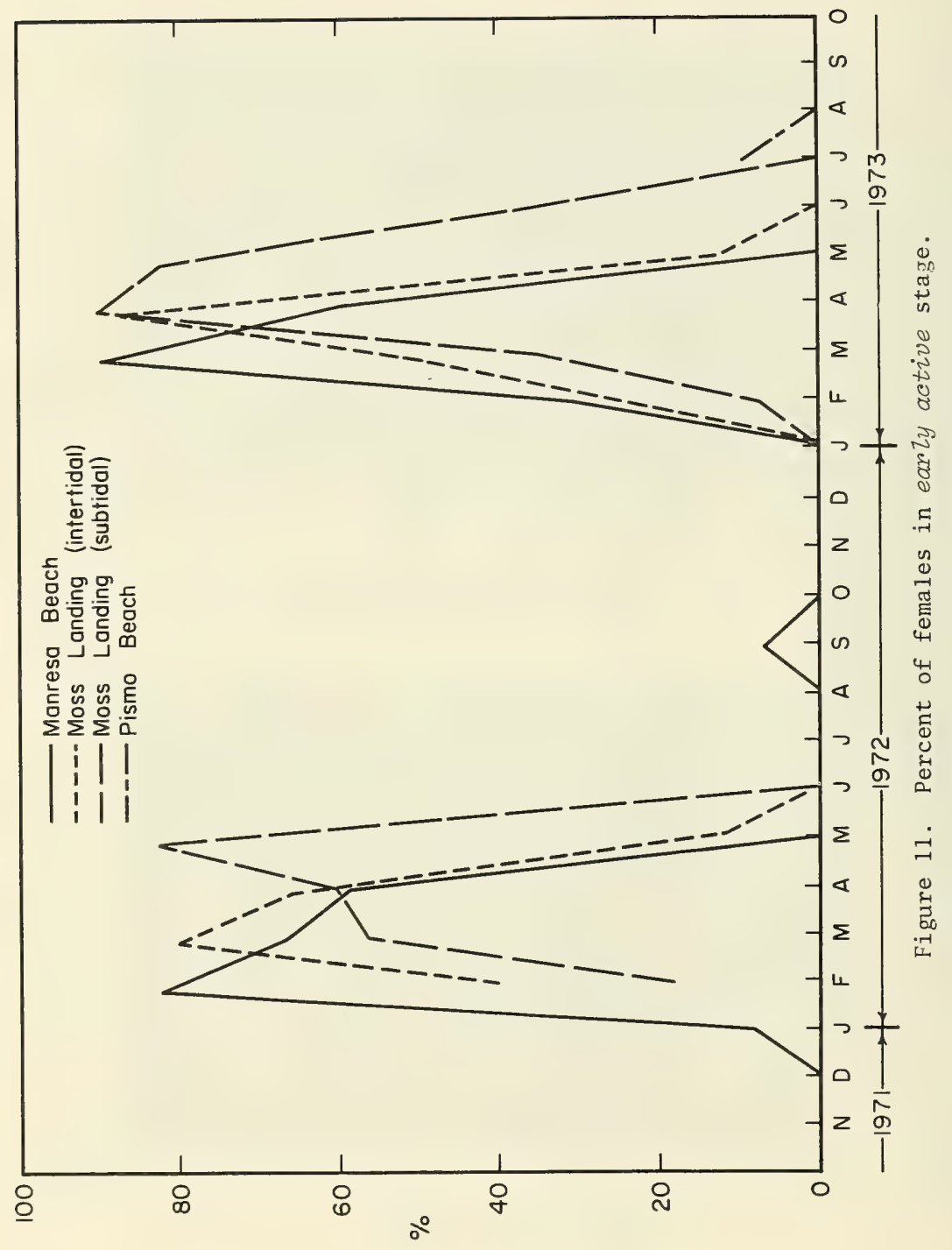




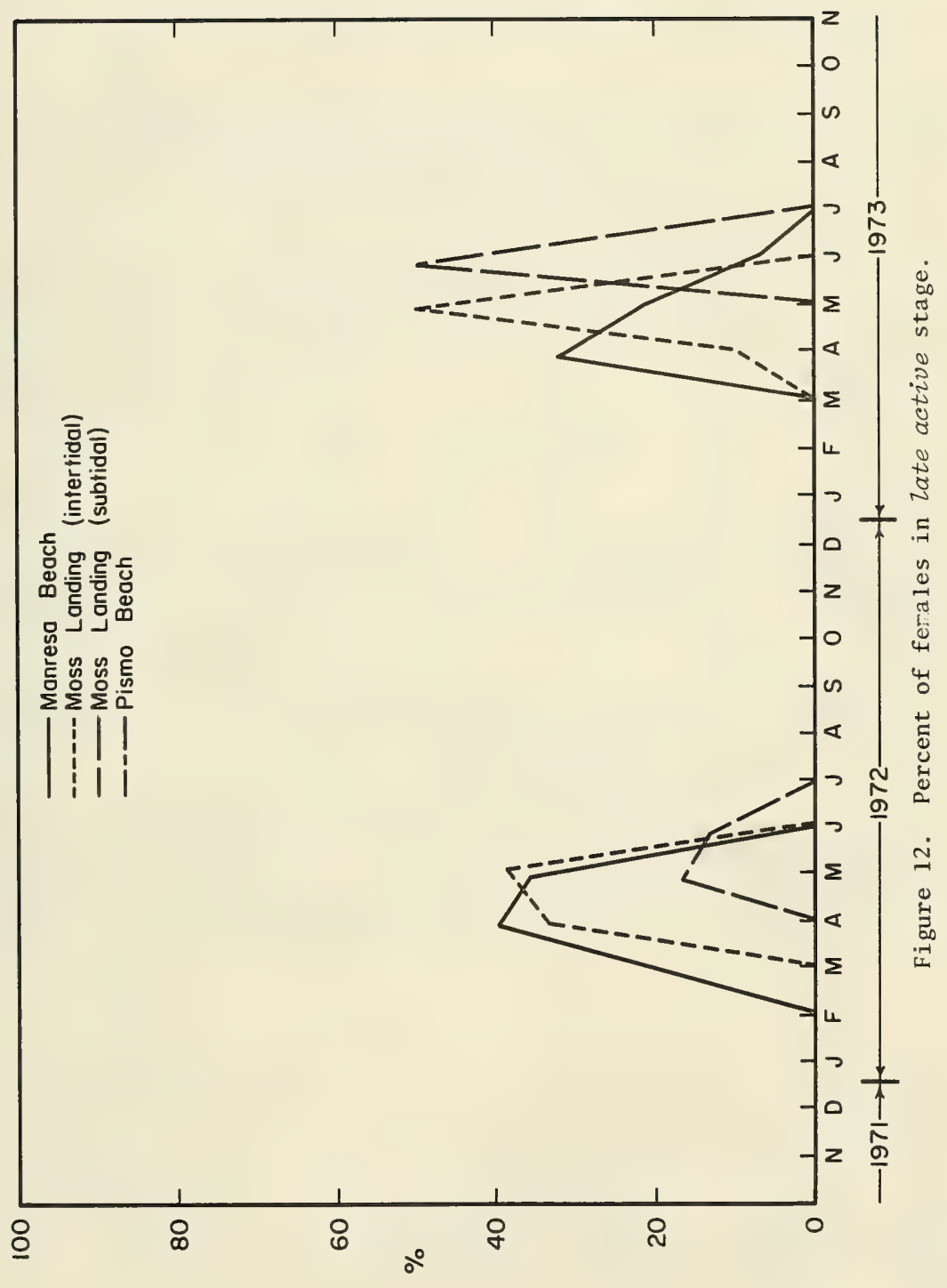




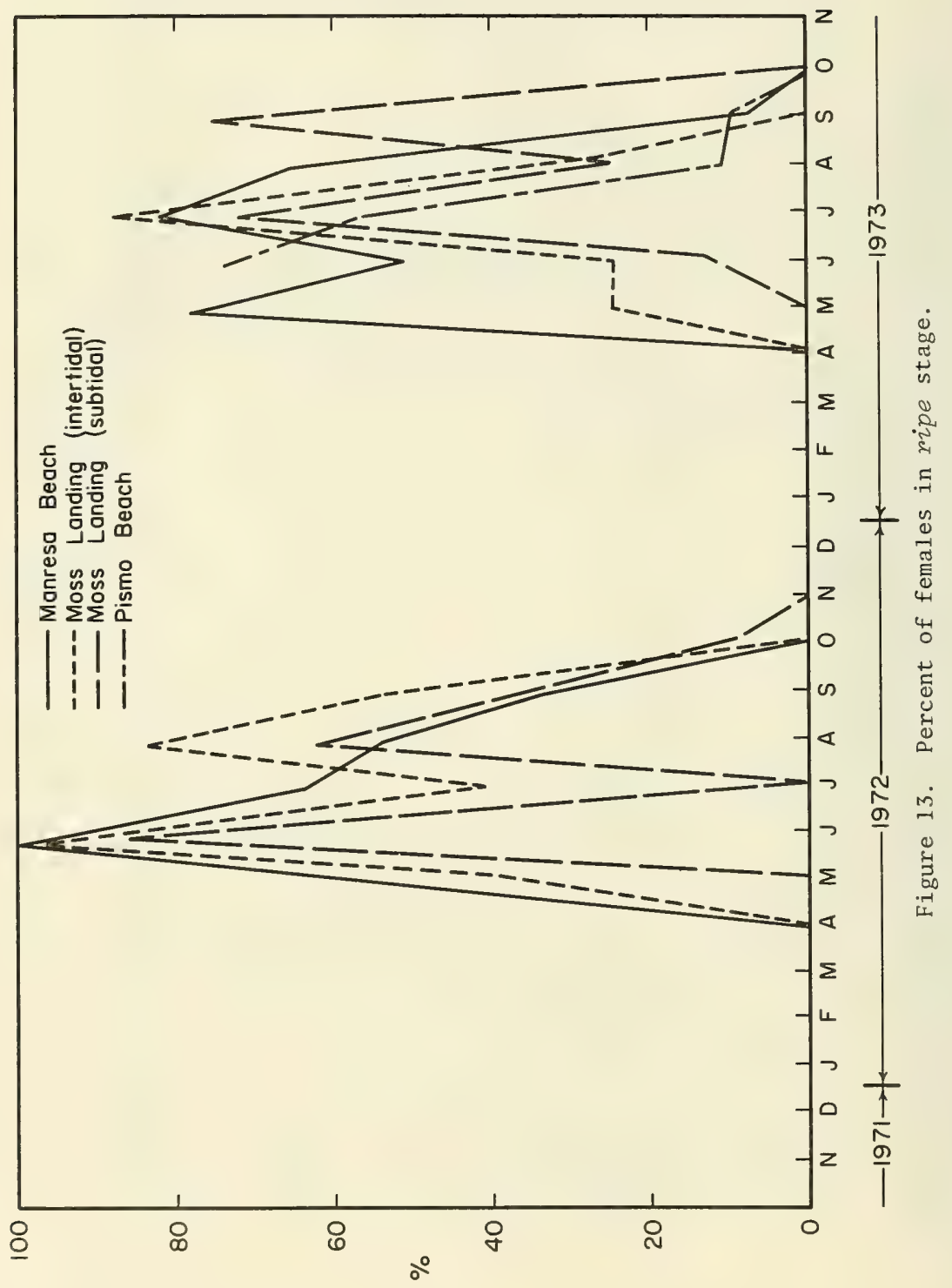


clams at Pismo Beach developed into the ripe stage 1 month earlier than intertidal or subtidal clams at Moss Landing.

The partly spent stage (Fig. 14) is important because it indicated onset of spawning and difficult to distinguish from the late active stage because in both stages the gonad was not completely full of eggs. Clams in the partly spent stage were found from May to December with the greatest occurrence from June to September (Fig. 15).

The spent stage of the clam was dominate from October to December (Fig. 15) although some clams were found in this stage throughout the year. The few ova remaining in some of the ovaries were usually completely resorbed by April, with the exception of subtidal clams from Moss Landing. In these clams the ova persisted longer and, in a few cases, were found in clams that were in the early stage of gametogenesis.

The inactive stage predominated from December to March but some clams were in this stage from October to May (Fig. 16).

b. Sex Ratio and Size at Maturity. Of the 289 clams examined, 142 were male, 144 were females (Fig. 17), and 3 were hermaphroditic. The small clams (less than 44 millimeters) and the large clams (more than $44 \mathrm{mj} 11$ imeters) have a sex ratio that is not significantly different from $1: 1$ (chi square, $0.50<\mathrm{P}<0.30$ ) suggesting that $\mathrm{sex}$, once determined does not change with age.

Most clams reached sexual maturity at a length of 20 millimeters (Fig. 17); however, one clam reached this maturity when 13 millimeters long.

c. Hermaphroditism. Although three hermaphrodite clams (Fig. 18) were found during the study, an analysis of the rate of occurrence of hermaphroditism was not made. A complete cross section of the foot would have to be examined to adequately check for hermaphroditism since usually only a few follicles are of the opposite sex (Coe, 1947) .

4. Discussion.

The main spawning period of Pismo clams at Pismo Beach and Monterey Bay occurred during September and October with some occurrences from June to August. Similar results on Pismo clams at San Diego were obtained by Coe (1947). The results were in contrast to the late spring or summer spawning common in the family Veneridae. Ansel1 (1961) reported that spawning in the European clams, Venus orata and Venus casina, occurred in May, Venus fasciata from February to July, and Venus striatula in summer. Mercenaria mercenaria, the northern quahog, spawns in summer (Loosanoff, 1937; Porter, 1964), Venerupis japonica and Protothaca staminia on the coast of British Columbia, spawn in. late spring (Quayle and Bourne, 1972), the European Venus pulZastra spawns in June (Quayle, 1952), and Saxidomus giganteus, smooth Washington clam species, spawns in April and May (Fraser and Smith, 1928). 


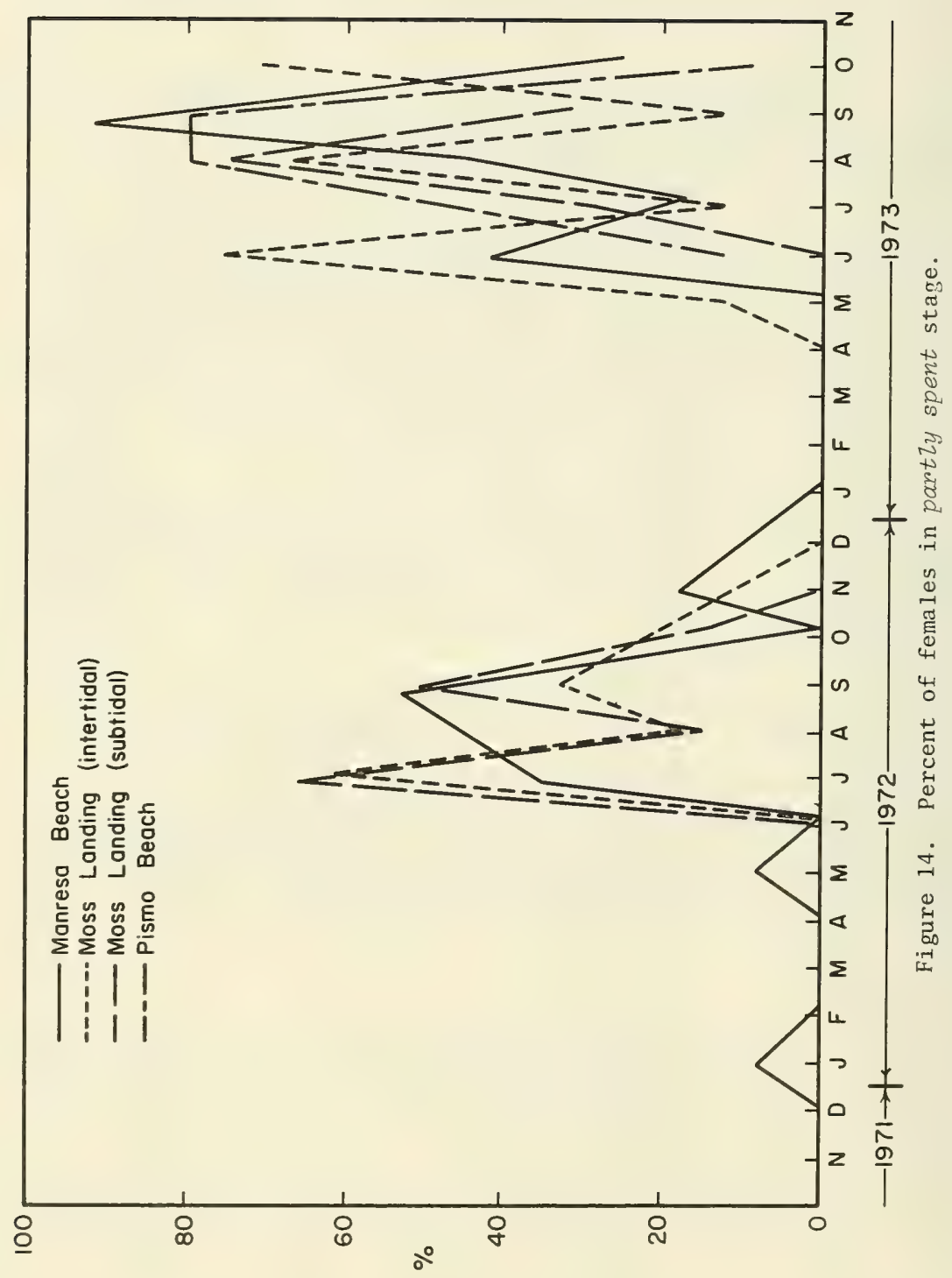




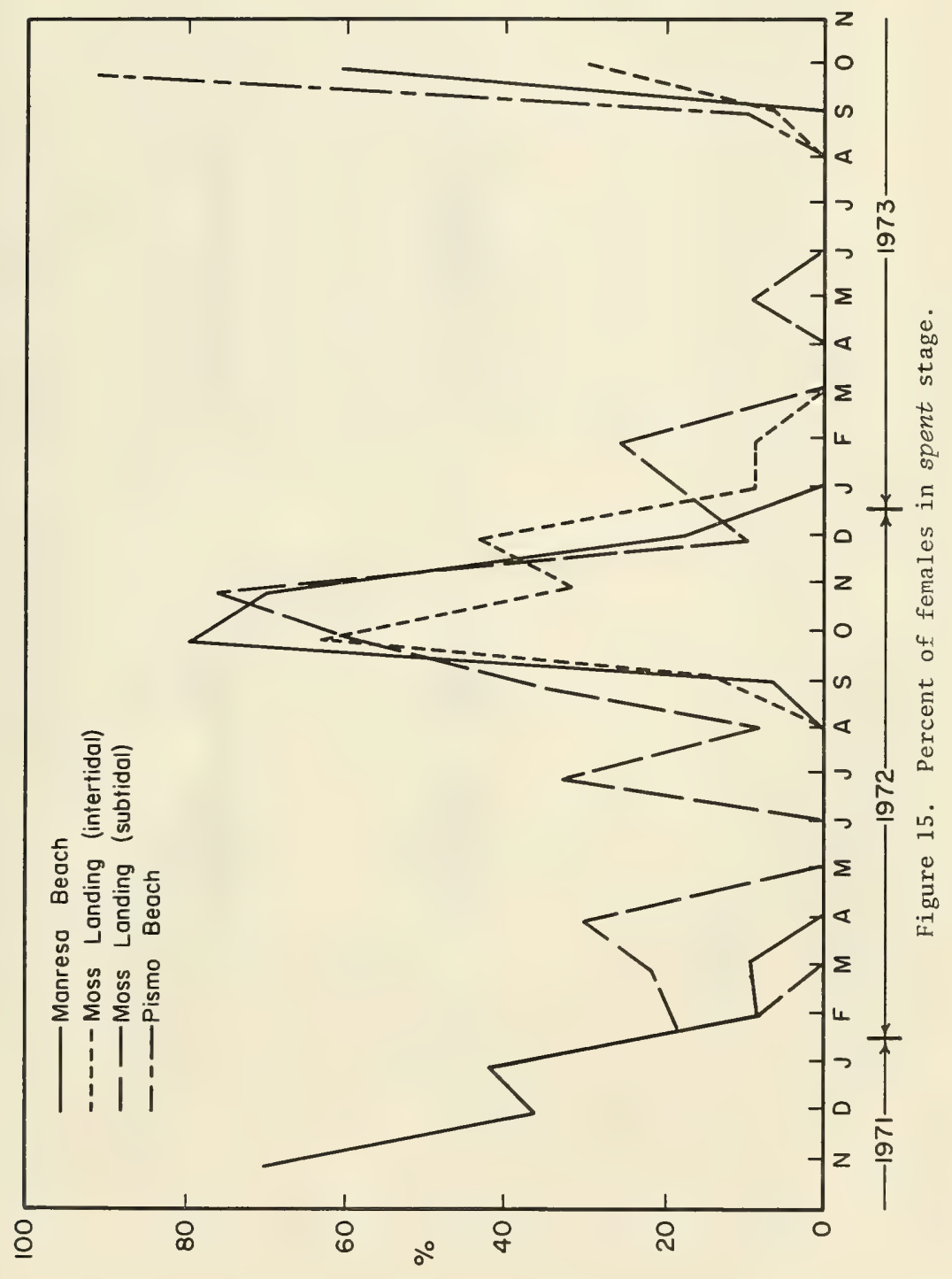




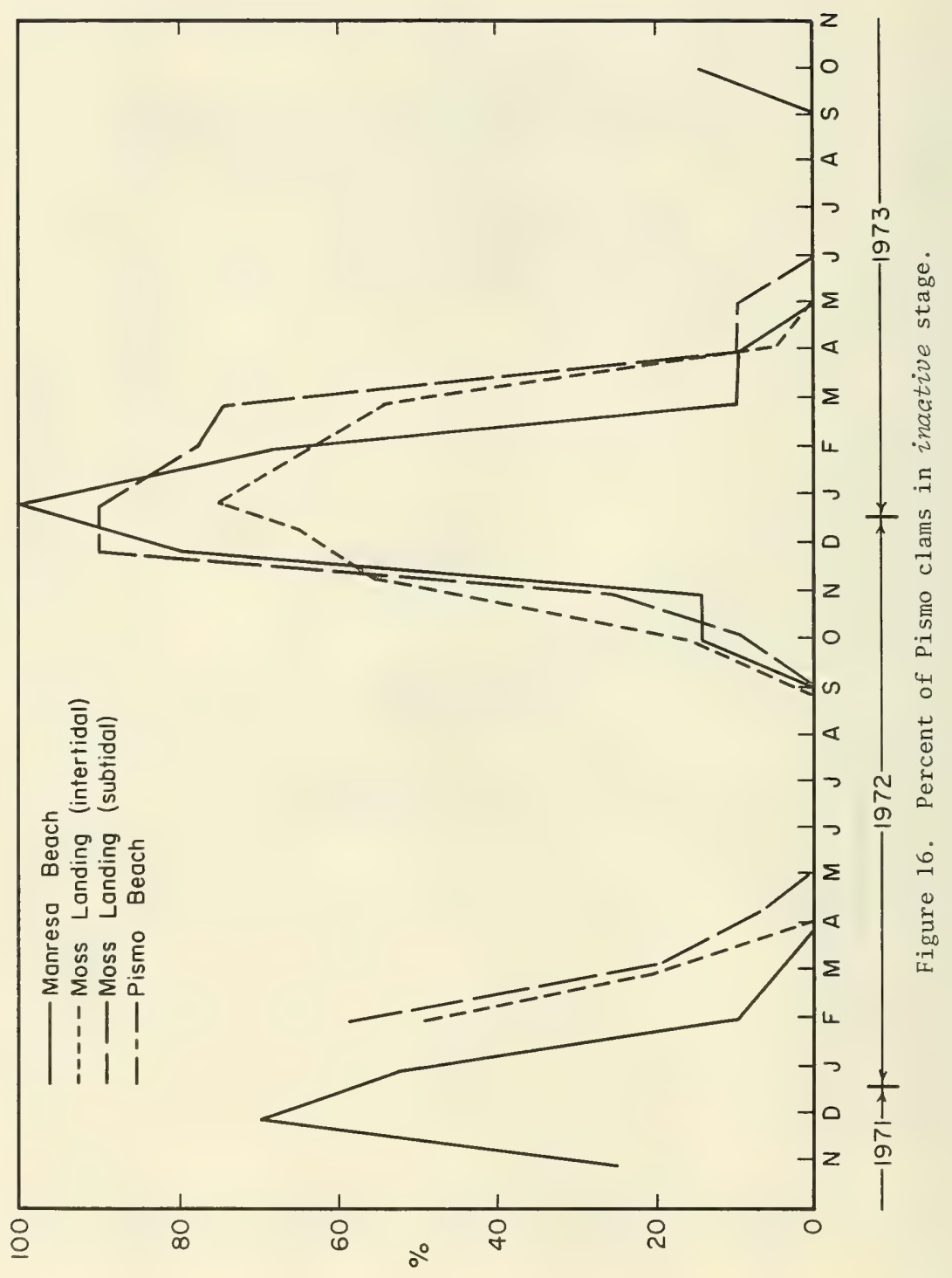



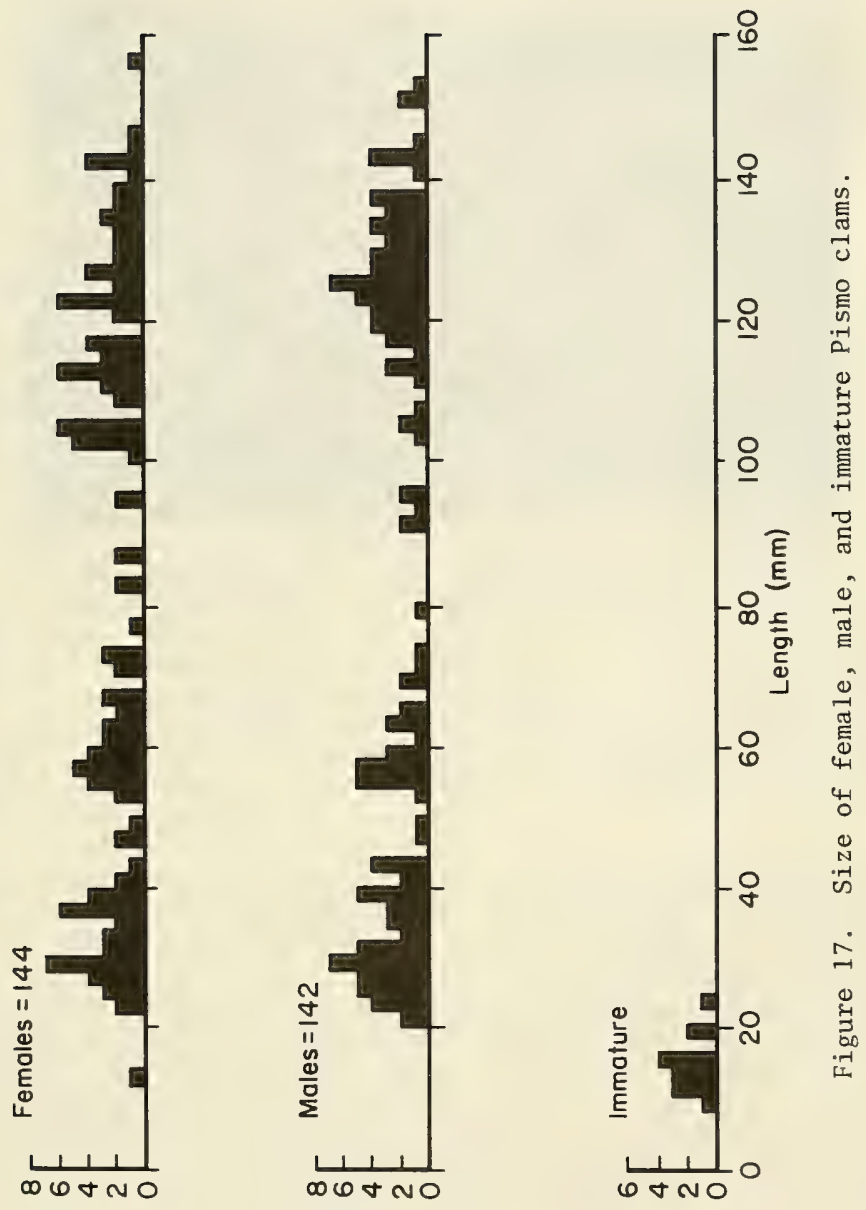

swoᅵว to JəqunN 


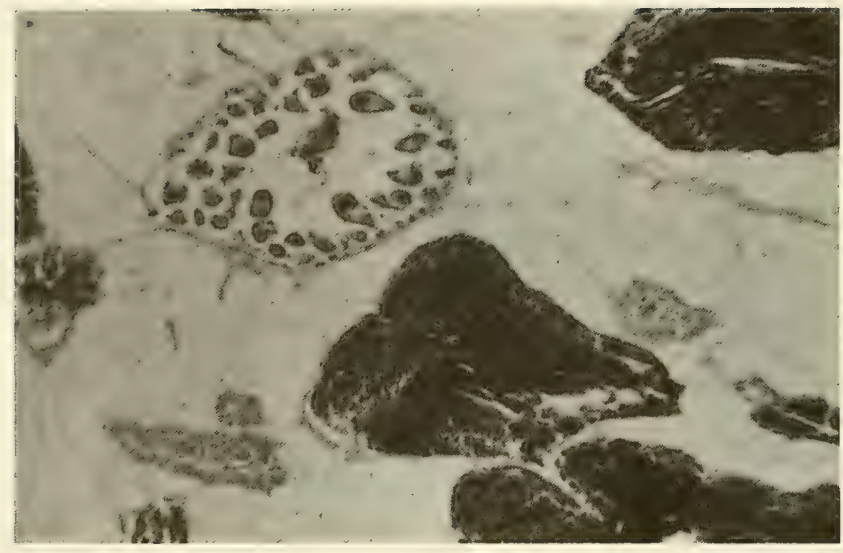

Figure 18. Hermaphrodite gonad (40X magnification). 
A similar late spring or summer spawning period has also been reported for many other Pacific coast bivalves including Ostrea Zurida, an 0lympia oyster, (Coe, 1932), Donax gouldi (Coe, 1953), Pododesmus cepio (Leonard, 1969), Siliqua patula, a razor clam, (Quayle and Bourne, 1972), and CZinocardium nuttalii, a Nuttall's cockle, (Quayle and Bourne, 1972). A rarer midwinter spawning period has been reported for Mytilus edulis, a common mussel, (Moore and Reish, 1969) and Mutilus californicus, a California mussel, (Young, 1942).

The common occurrence of late spring or summer spawning when the water temperature is near its maximum, suggests that temperature may be an important factor in governing the reproductive cycle. Orton (1920) and Nelson (1928) first suggested that each species had a critical minimum temperature requirement and would not spawn below it. The importance of water temperature during spawning was further indicated by Loosanoff and Davis (1963) who conditioned many bivalve species for out-of-season spawning at various times of the year.

Sufficient food was also found to be a necessary requirement for gametogenesis and spawning (Sastry, 1966, 1968). Food for the Pismo clam was studied by Coe (1947) who found the clams digesting naked dinoflagellates, small diatoms, and detritus. He suggested that most of the phytoplankton ingested was not fully digested, and that the principal source of nutrition was detritus. The latter suggestion seems consistent with the food habits of other sand beach organisms, i.e., Emerita analoga, a mole crab, and Blepharipoda occidentalis, a spring sand crab, and suggests the reason for the concentration of clams in the surf zone with the greatest detritus concentration.

To correlate between the gonadal cycle of the Pismo clam and both water temperature and food data, temperature, chlorophy11 a, phaeopigment and stage of gonadal maturity data were compiled on a monthly basis and are given in Table 7. Chlorophyll a was used as an indicator of phytoplankton standing crop; phaeo-pigment may be an indicator of phytoplankton detritus (Lorenzen, 1967) although its real significance is uncertain. Temperature, chlorophyll a, and phaeo-pigment increased during the months from February to June (Table 7). If an increase in phytoplankton pigment indicates an increase of utilizable food for Pismo clams, the clams may use this increase for development of their gonads. Clams require a substantial amount of energy since the gonad increases from 12 percent of the body tissue weight in January to 28 percent in September (Giese, et a1., 1967). Other sources of food, such as macro-algae detritus, that are nonplanktonic in origin may be important in supplying the necessary energy for gonad development but estimates of their abundance or seasonal variations are not available.

Most of the gametes are shed in September and October when the water temperature and values of chlorophyll a and phaeo-pigment have reached a fall maximum. Spawning may be triggered by the increase in food or temperature in the fall; however, other factors may also be important, 


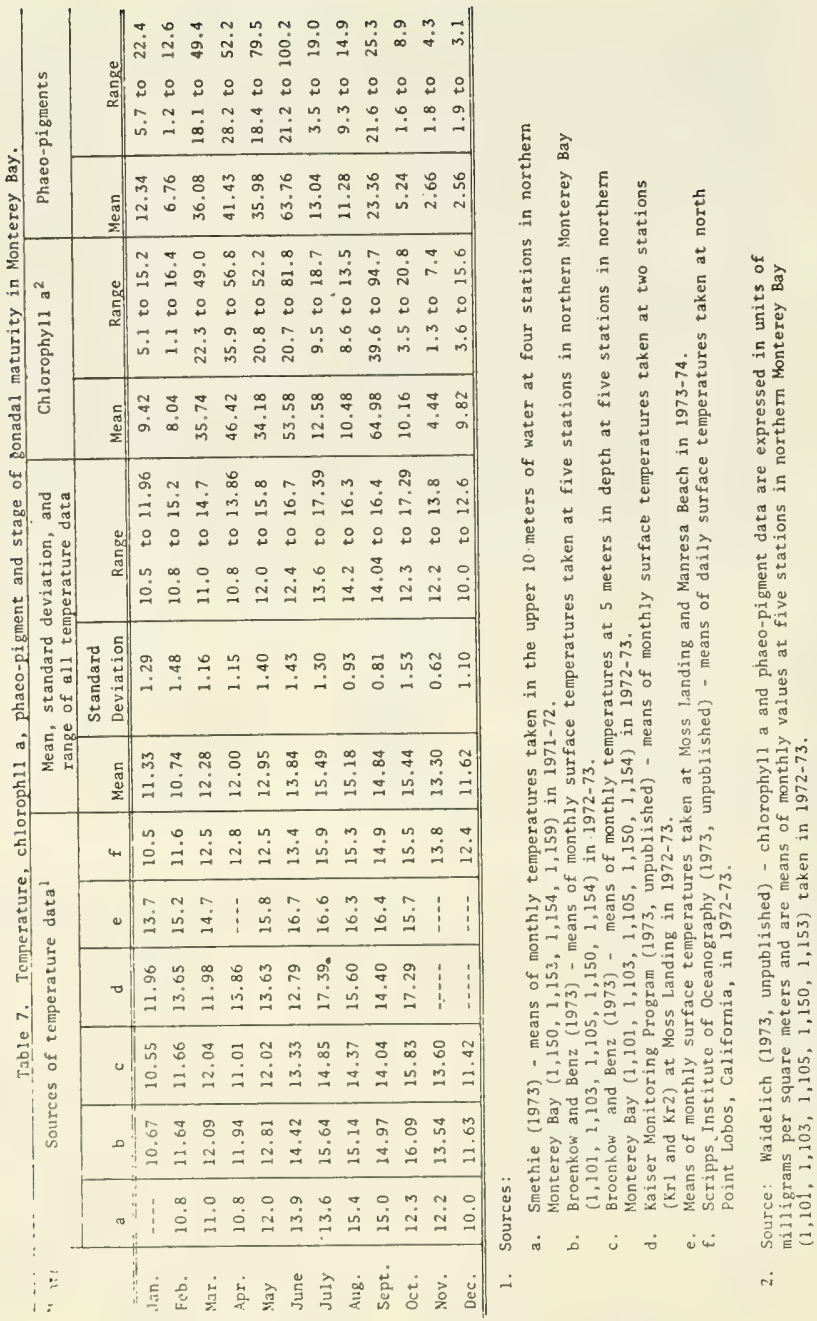


i.e., I unar periodicity (Korringa, 1947; Mason, 1958; Mileikovsky, 1970), or various dissolved organic substances (Galtsoff, 1961). Regardless of what triggers spawning, it is advantageous for the clams to spawn in the fall so their pelagic larvae will have food from the fall phytoplankton bloom.

Coe and Fitch (1950) reported that Pismo clams in Baja, California (Mexico) have an extended spawning season compared to the clams at San Diego and Pismo Beach; however, length of spawning season does not decrease from San Diego to Monterey Bay. Most gametes are shed in September and October at San Diego (Coe, 1947), Pismo Beach, and Monterey Bay, even though Monterey Bay is near the northern limit of their range. The average temperature difference between San Diego and Pacific Grove, California, for the spawning months of September and October is $4.82^{\circ}$ Celsius (range 2.61 to 6.99), which is based on daily temperatures taken over an 18-year period (U.S. Department of Commerce, 1956). Therefore, Pismo clams spawn at different temperatures at the two locations, suggesting that there is not a single critical spawning temperature for all populations of Pismo clams. However, it does not rule out the possibility that the clams may spawn in response to yearly maximum temperatures occurring in September and October. The spawning season at San Diego may be delayed because spawning is governed by temperature changes over the year. Another possible explanation is that different populations of Pismo clams, as well as the eastern oysters, Crassostrea virginica (Loosanoff, 1969), are genetically adapted to spawning at different temperatures.

In Monterey Bay (Fig. 17) and San Diego (Coe, 1947), the Pismo clams first develop mature gonads at about 20 millimeters in length. However, because of a higher growth rate of juvenile clams at San Diego, clams develop mature gonads their first summer in San Diego (Coe, 1947) and their second summer in Monterey Bay. This rapid maturity is in contrast with other Pacific coast bivalves, such as the smooth Washington clam which matures when it is from 3 to 5 years of age and 40 millimeters long, and Nuttall's cockles which matures at 2 years of age anc' 40 milimeters long (Quayle and Bourne, 1972).

Pismo clams were first thought to be hermaphroditic (Weymouth, 1923), but Coe (1947) later determined the clams were dioecious with less than 1 percent hermaphroditic. Samples from Monterey Bay and Pismo Beach showed that less than 1 percent were hermaphroditic. Occasional hermaphrodites are not uncommon in dioecious bivalves (Loosanoff, 1936; Ropes, 1966). The sex ratio of Pismo clams in Monterey Bay was not significantly different from $1: 1$ in large (more than 44 millimeters) and small (less than 44 millimeters) clams. Coe (1947) found 1.2 females to 1 male in large clams in San Diego, which was also not significantly different from a 1:1 ratio. 
Gametogenesis begins in February and most clam gonads are in the ripe stage by May or June. Although most remain in this stage throughout the summer, some partial spawning does occur. Complete spawning occurs mainly during September and October in Monterey Bay and Pismo Beach. $\mathrm{Clam}$ gonads reach an earlier ripe stage at Manresa Beach and Pismo Beach, and a later ripe stage at the subtidal Moss Landing station. Intertidal Moss Landing clams reach the ripe stage at an intermediate time. Gametogenesis and time of spawning may be correlated with water temperature and phytoplankton abundance in Monterey Bay. The sex ratio for large and small clams did not differ significantly from 1:1. Clams mature when 20 millimeters long in Monterey Bay and San Diego, but because of higher growth rates of juvenile clams at San Diego, the clams at Monterey Bay ripen 1 year later than clams at San Diego.

\section{AGE AND GROWTH}

\section{Introduction.}

The first studies of the growth of Pismo clams were done at Pismo Beach by Weymouth (1923), who noted the existence of age classes in size-frequency plots and demonstrated the existence of rings in the shell which he assumed to be annual rings. He also drew the first growth curve for the species. Herrington (1930) confirmed Weymouth's work and added data from other locations, including Monterey Bay. The most recent study of growth in Pismo clams was done by Coe and Fitch (1950) who monitored 5 years of growth in several southern California populations and noted fluctuations in the populations. Until this study, the growth in Pismo clams had not been investigated for more than 20 years.

This study had two major objectives: (a) Establish the growth rates of different-sized clams in the natural environment in Monterey Bay and from that, construct a generalized growth curve, and to provide an independent assessment of the validity of annual growth rings in Pismo clams which were used by three previous investigators to assess age structure and growth; and (b) determine the age structure of natural populations of intertidal clams in Monterey Bay.

\section{Methods and Materials.}

Several methods were used to hold marked clams for growth studies. To determine growth rates of different-sized clams, individual clams were marked with a unique number, the length measured, and returned to the beach. Pismo clamshells are exceedingly thick, so a permanent number was engraved in the outer she11 with an engraving tool. Over the 2-year period, a total of 997 clams were marked.

The first group of 161 marked clams was established on 29 February 1972 at Moss Landing at a depth of 10 feet below mean lower low water (MLLW). 
The area was marked by fence anchors at each corner of a 20-square-foot area. Erosion of the bottom destroyed the markers soon after establishment, and the location of the bed was lost for 5 months. The bed was rediscovered the summer of 1972, and only 34 clams were recovered by September. A second subtidal bed of $95 \mathrm{clams}$ was then reestablished on 19 December 1972, using larger fence anchors and smaller buoys to mark the location. This bed was located 15 feet below MLLW to avoid losses from wave action. However, only eight marked clams were recovered from this bed on 22 February 1973, and no further recaptures were made.

The most successful study site was established at the -1.0 -foot tide level in the intertidal zone in front of the Moss Landing Marine Laboratories. The site was marked with a fence anchor and planted with 108 marked clams on 19 Apri1 1972 and an additional 42 clams on 17 May 1972. On 30 June 1972, 26 clams were recovered and remeasured.

The intertidal bed was sampled several times after June 1972, and growth data were obtained for five periods: 17 May to 30 June (44 days), 30 June to 9 August (40 days), 11 August to 28 September (48 days), 28 September to 26 0ctober ( 28 days), and 26 October to 21 November (26 days).

The bed was resampled on 21 December 1972, and 21 marked clams were recovered, remeasured, and returned to the bed, with an additional 117 newly marked clams and 17 marked clams which had become too 1 arge for the pails at the pier. A total of 165 clams was returned to the intertidal bed.

On 18 January 1973, the bed was sampled again, and only 25 clams recovered. In the interval between the December and January sampling, storms had increased the sand depth more than 1 foot in the intertidal bed which probably accounted for the few recoveries.

After more storms, the intertidal bed was sampled again on 15 February 1973, and only six marked clams were recovered. However, conditions were poor for sampling. An additional 37 marked clams were added to the bed.

In March, no clams were recovered from the intertidal bed because of unfavorable tides and weather. Extremely heavy wave action between mid-February and mid-March changed the beach contours at Moss Landing where the intertidal bed was located. The primary change was a 3-foot decrease in sand depth, which probably caused the loss of many clams.

On 10 Apri1 1973, 27 clams were recovered, remeasured, and returned with an additional 72 clams. On 8 May 1973, 45 clams were recovered and remeasured, and returned with 90 newly marked clams. Seventy-nine clams on 3 June 1973 and 40 clams on 3 July 1973, were recovered, remeasured, and returned.

Another method of obtaining growth data was to suspend a rack with measured clams and sand in two 5 -inch plastic tubes from the end of 
Sandholt Pier at Moss Landing, 2 feet below MLLW. On 19 May 1972, 29 small clams (14.1 to 35.4 millimeters long) were placed in the tubes and retained in 2 -millimeter-mesh covers. When the clams were recovered on 30 June 1972, some had been killed by fouling organisms which were attracted to the mesh and had cut off water circulation to the interior. The surviving clams were remeasured, the others substituted, and the tubes were replaced by two plastic buckets without the mesh covering.

On 20 December 1972, 33 small clams were recovered from these buckets. The largest $17 \mathrm{clams}$ were placed in the intertidal bed, and the other 16 were returned to the buckets with 98 newly marked small clams.

On 20 January 1973, it was discovered that the cables had been cut by vandals and the buckets lost. Ten days later, the buckets were replaced with 64 clams in special racks at two new locations near the pier. On 22 February 1973, it was determined that the waves had released the buckets, losing all clams. A similar attempt in March met with the same fate. The buckets with 34 clams were reestablished in strong metal frames on 9 Apri1 1973. On recovery, 8 May 1973, it was found that all but one small clam had apparently been killed by two crabs that had entered the buckets. An additional 50 newly marked clams were placed in the buckets and covered with mesh to prevent entry of crabs. This method worked well. Fifty clams on 3 June 1973 and 44 clams on 3 July 1973 were recovered, remeasured, and returned.

Because of the small number of recoveries at each time interval from the individual growth areas, and because of the losses due to weather and vandalism, the data from each measurement period were combined. Therefore, al1 recaptures from the intertidal, subtidal, and bucket sites were used to figure rates for any given interval of calculated growth rate.

However, reasonable data were salvaged from the following time intervals: 30 June to 9 August 1972; 11 August to 28 September 1972; 28 September to 26 October 1972; 26 October to 20 November 1972; 10 April to 8 May 1973; 8 May to 3 June 1973; and 3 June to 3 July 1973.

The data were analyzed in several ways. Plots of growth increment against initial size were subjected to linear-regression analysis. Since the time intervals in days were different among the sampling periods, the instantaneous growth rate $(\mathrm{Kg})$ was calculated for each interval (Simpson, Roe, and Lewoutin, 1960).

Finally, the age structure of the clam population at Monterey Bay Academy was assessed, using a graphical analysis of size-frequency data. This method (Harding, 1949; Cassie, 1954) involved plotting cumulative percentages of each size clam on probability paper, and resolving the result into the means and standard deviations of the age groups in the population. 
3. Results and Discussion.

The results of the regression analysis of the seven growth periods are given graphically in Figure 19. The arithmetic instantaneous growth rate $(\mathrm{Kg})$ for each of the periods is given in Table 8 and Figure 20.

The seven regression lines are straight and represent a linearregression analysis. Growth in most biological systems is generally found to be an exponential function best fitted by a curved line. Since it was not apparent by observation of scatter diagrams whether the results were best filled by a linear or exponential function, both 1 inear and curvilinear regressions on all data were run and compared with the correlation coefficients. All the correlation coefficients from rectilinear and curvilinear were so close that it appeared to make no difference. Therefore, the linear analyses were chosen for presentation.

In many growth studies, the growth rate is uniform except among the youngest and oldest clams where the rate is accelerating or decelerating. When the data are plotted, a typical sigmoid growth curve is produced. Since growth measurements of clams below 12 millimeters and above 125 millimeters in length were lacking in regions where rapid growth rate changes occurred, the data fit a linear regression. Typical curved growth lines were reported for Pismo clams by Weymouth (1923) and Coe and Fitch (1950), but examination of the graphs indicated that the growth was essentially linear between $10 \mathrm{millimeters}$ and $110 \mathrm{millimeters,} \mathrm{the} \mathrm{range}$ of most length measurements.

The seven regression lines were all significantly different from 0 and showed a negative slope, indicating a decrease in growth increment with an increase in size (= age).

To determine if the growth rates for all clams differed at different times of the year, two separate analyses were run. First, the slope $\left(b_{y x}\right)$ of each regression line against the slope of the other regression lines of that year was tested to see if there was a significant difference. Two tests were used, $F$ and $t$ (Sokal and Roh1f, 1969). Results of the tests indicated a significant difference $(P=1$ ess than 0.05$)$ between the following paired intervals: 30 June to 9 August 1972 and 11 August to 28 September 1972; 30 June to 9 August 1972 and 26 October to 20 November 1972; 11 August to 28 September 1972 and 26 October to 20 November 1972; 28 September to 26 October 1972 and 26 October to 20 November 1972; 8 May to 3 June 1973 and 3 June to 3 July 1973; and 10 April to 8 May 1973 and 3 June to 3 July 1973. The growth rate of the Pismo clam in Monterey Bay, as illustrated in the analysis of the mean daily growth rate, $\mathrm{Kg}$, was not constant throughout the year. The mean daily growth rate varied considerably over the course of the year (Table 8 and Fig. 20). The highest rates occurred in the summer and early fall, and the lowest in late fall and spring. The meager existing data suggest that the growth rate is low in the winter. Coe and Fitch (1950) found that the growth rates were lowest from November through February and highest in the summer. 


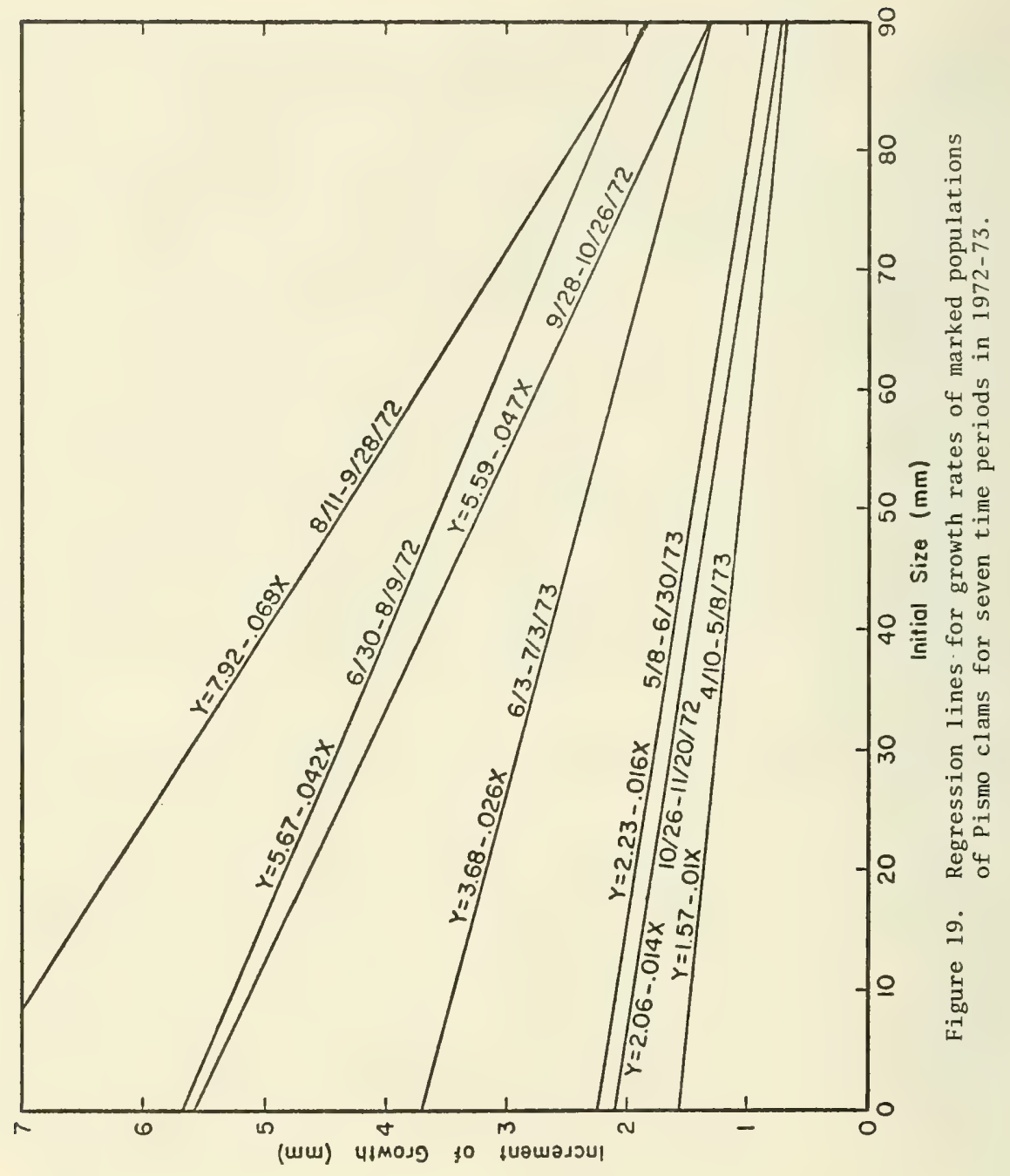


Table 8. Calculation of $\mathrm{Kg}$, the mean daily arithmetic growth rate for seven time periods in 1972-73.

\begin{tabular}{|c|c|c|c|c|c|c|c|c|}
\hline & Time & perio & & Days & $\mathrm{n}$ & $\bar{x}$ & $\bar{y}^{1}$ & $\mathrm{Kg} \mathrm{mm} / \mathrm{day}$ \\
\hline \multicolumn{9}{|c|}{1972} \\
\hline 30 & June & to 9 & Aug. & 40 & 188 & 51.69 & 3.477 & 0.0869 \\
\hline 11 & Aug. & to 28 & Sept. & 48 & 114 & 70.93 & 3.075 & 0.064 \\
\hline 28 & Sept. & to 26 & oct. & 28 & 85 & 64.71 & 2.585 & 0.092 \\
\hline 26 & Oct. & to 20 & Nov. & 26 & 75 & 52.256 & 1.437 & 0.055 \\
\hline \multicolumn{9}{|c|}{1973} \\
\hline 10 & Apr. & to 8 & 3 May & 25 & 38 & 86.7 & 0.7 & 0.028 \\
\hline 8 & May & to 3 & 3 June & 26 & 107 & 55.9 & 1.4 & 0.054 \\
\hline 3 & June & to 3 & 3 July & 30 & 75 & 48.9 & 2.4 & 0.08 \\
\hline
\end{tabular}

1. Mean growth increment. 


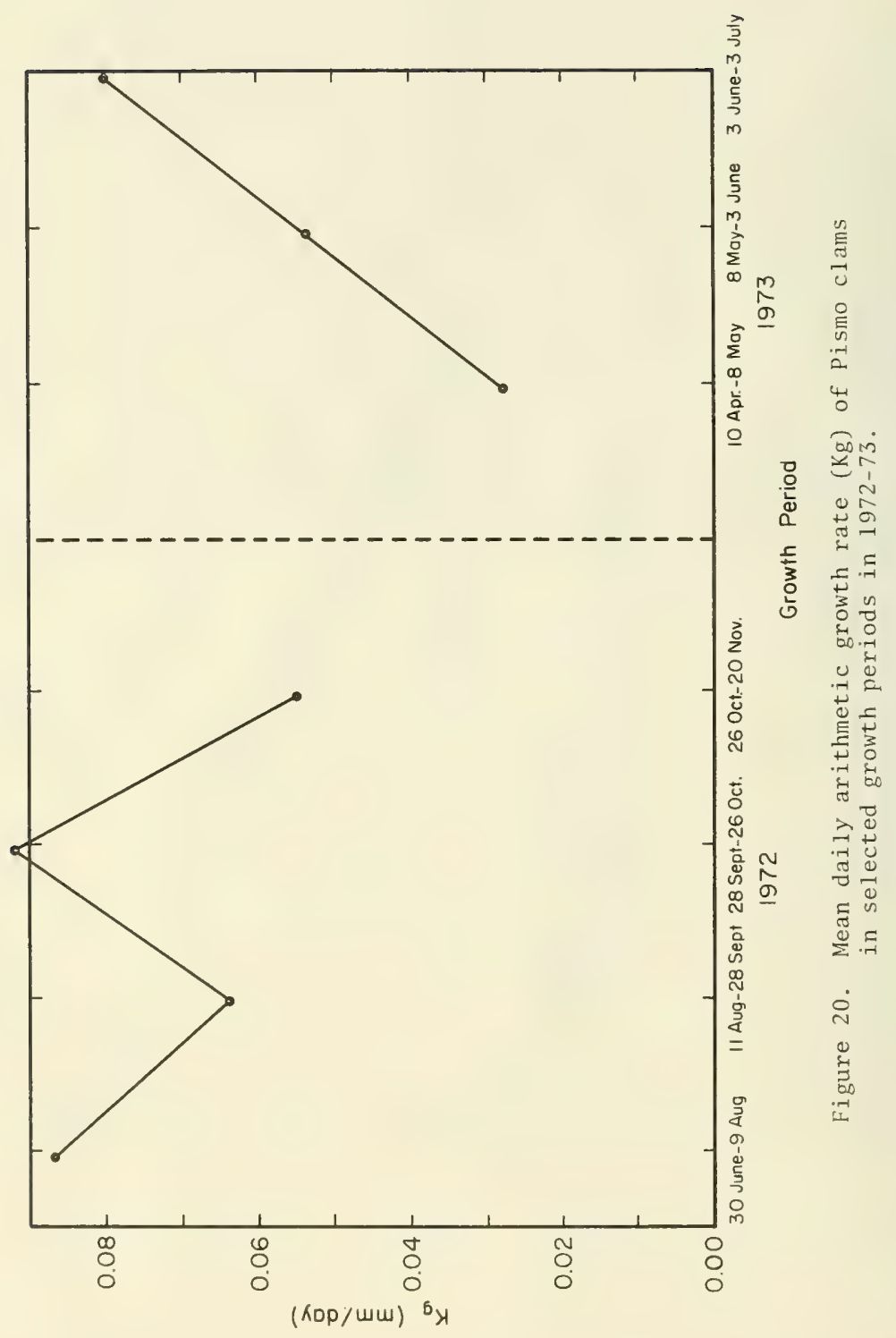


Herrington (1930) also showed that growth slowed in the winter and led to formation of rings in the shells.

Since the Pismo clam has one major spawning season per year, year classes in the adult population can be identified. Theoretically, the year classes should be apparent as modes in a size-frequency graph. The modes may be resolved by graphical analysis on probability paper (Harding, 1949; Cassie, 1954) to estimate the mean size and standard deviation of the component year classes.

On 12 October 1973, 71 quadrats (1 square meter) were taken at Monterey Bay Academy and 303 Pismo clams were collected and measured. The clams were grouped by length in 4-millimeter-size classes, a sizefrequency diagram was prepared, and the modes were resolved into component age classes on probability paper. The results are given graphically in Figure 21. Five groups were found which were assumed to represent five age classes.

Herrington (1930) and Coe and Fitch (1950) calculated ages of clams at various lengths; Herrington, by counting the annual rings in the shell, and Coe and Fitch, by actual measurement of marked clams. Only Herrington reported the average sizes for the age classes in Monterey Bay. Comparison of the results of this study with Herrington and Coe and Fitch is given in Table 9. The means of the length (age) do not agree. The large disagreement in year class $V$ is easily explained. Few clams over 110 millimeters in length were obtained to validate mean and variance which was believed due to the heavy clamming pressure which cropped off everything near the legal limit of 126 millimeters. A single clam of legal size or above was not collected, indicating the clams were probably removed by clammers each year. Therefore, what is designated as class V with a mean of $120 \mathrm{millimeters}$ is probably a combination of all the survivors of older age classes. The $120 \mathrm{millimeters} \mathrm{average} \mathrm{is} \mathrm{simply}$ an average of all the age classes greater than class IV.

The year class $\mathrm{I}$, with a mean length of 11 millimeters, represents clams spawned in 1972 and their first year. The clam's average size is less than reported by Herrington for Monterey Bay and Coe and Fitch for La Jolla, but well within the range reported for Pismo Beach (Table 9). A similar situation prevails for classes II and III. The mean length of class IV appears to be greater than that at La Jolla or Monterey Bay. However, there is an extremely large spread in Herrington's data.

Four age classes are believed to be present at Monterey Bay Academy and a fifth size class comprising the few representatives of all clder classes. The growth rate of clams in Monterey Bay is also slower than in more southern localities.

\section{Conclusions.}

Small pismo clams in Monterey Bay grow at greater rates than large clams at all seasons of the year. The rates of growth for all clams vary 


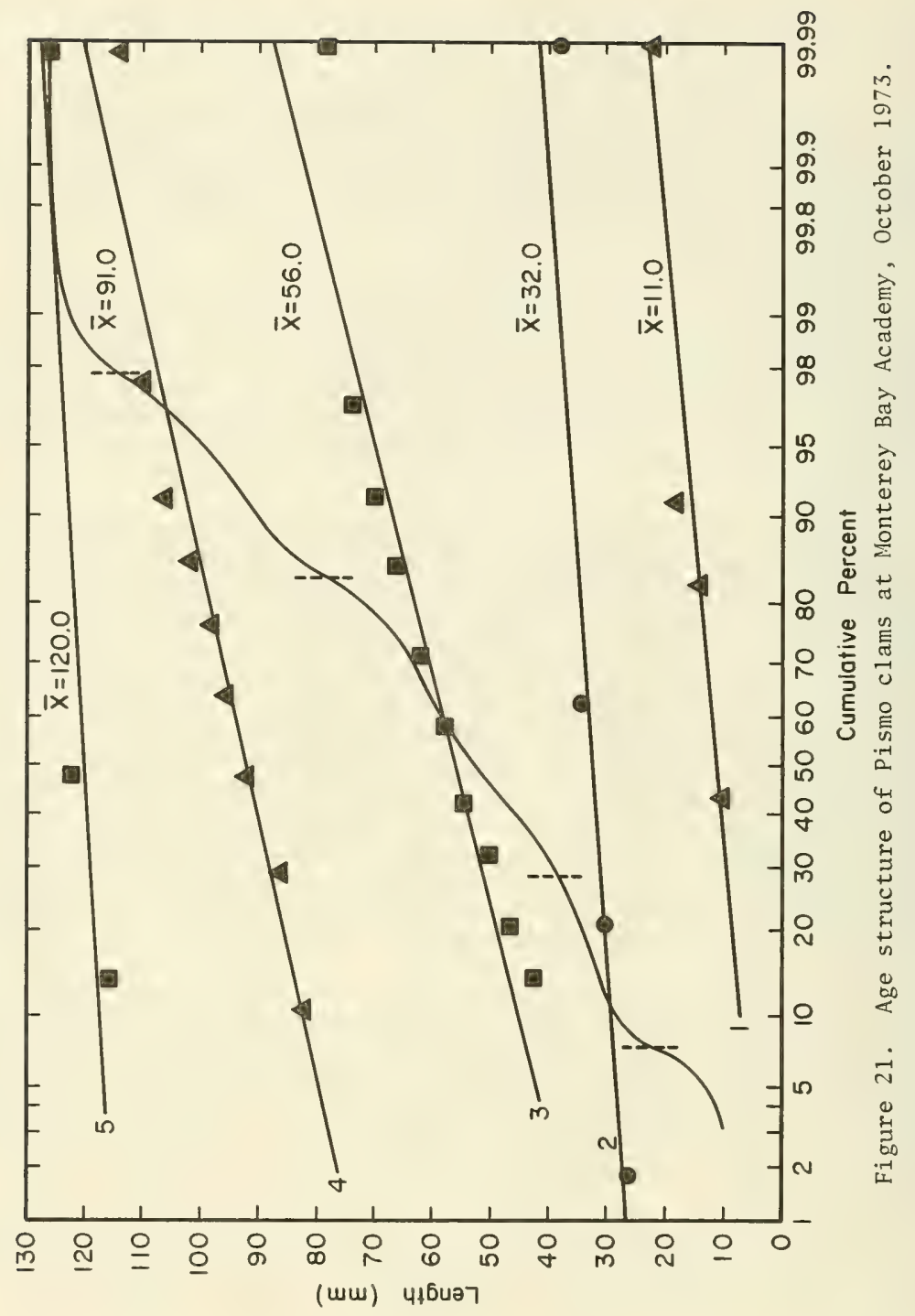




\begin{tabular}{|c|c|c|c|c|c|c|c|c|c|c|}
\hline $\begin{array}{l}\text { Eे } \\
\text { प्ّ } \\
\text { Uુ }\end{array}$ & 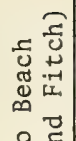 & $\begin{array}{l}0 \\
\infty \\
\underset{\pi}{\Xi} \\
\approx\end{array}$ & $\begin{array}{l}\stackrel{M}{N} \\
0 \\
+ \\
0\end{array}$ & $\begin{array}{l}\text { in } \\
\circ \\
+2 \\
\text { in }\end{array}$ & : & ! & i & ! & i & i \\
\hline बे & \begin{tabular}{cc}
$E$ & $\pi$ \\
$n$ & \\
\hdashline-1 & 0 \\
$n$ & 0 \\
& 0
\end{tabular} & $1 x$ & $\stackrel{+}{i}$ & $\stackrel{q}{\stackrel{9}{\sigma}}$ & i & ! & i & i & i & i \\
\hline 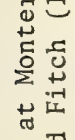 & 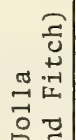 & 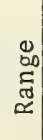 & $\begin{array}{l}\text { m } \\
\stackrel{0}{+} \\
\sim\end{array}$ & $\begin{array}{l}\text { in } \\
\text { in } \\
\text { in }\end{array}$ & $\begin{array}{l}\text { o } \\
\circ \\
+ \\
\text { in }\end{array}$ & $i$ & $i$ & $i$ & ! & i \\
\hline $\begin{array}{ll}\infty & 0 \\
n & 8 \\
\pi & 0 \\
-1 & 0\end{array}$ & 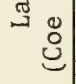 & $\mid x$ & $\stackrel{\nabla}{\sim}$ & $\begin{array}{l}\dot{j} \\
\dot{J}\end{array}$ & $\ddot{n}$ & $\begin{array}{l}q \\
\infty\end{array}$ & i & $\begin{array}{l}\vdots \\
\vdots\end{array}$ & $\begin{array}{l}1 \\
i \\
i\end{array}$ & i' \\
\hline 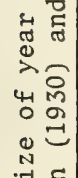 & స్ & $\begin{array}{l}0 \\
\infty \\
\Xi \\
\approx \\
\approx\end{array}$ & $\begin{array}{l}\text { त) } \\
\text { ㅇ } \\
\text { 맘 }\end{array}$ & $\begin{array}{l}\infty \\
\text { n } \\
\stackrel{0}{+} \\
\vec{m}\end{array}$ & $\begin{array}{l}+ \\
\infty \\
+ \\
+ \\
\text { in }\end{array}$ & $\begin{array}{l}\text { ? } \\
\text { - } \\
0 \\
+ \\
5\end{array}$ & $\begin{array}{l}\text { I } \\
\stackrel{+}{+} \\
N \\
\infty\end{array}$ & 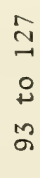 & $\begin{array}{l}\infty \\
\underset{\sim}{\sim} \\
\stackrel{0}{+} \\
\infty \\
\infty\end{array}$ & 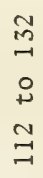 \\
\hline 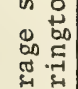 & 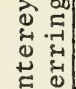 & in & $\begin{array}{l}\text { ปै } \\
\dot{m}\end{array}$ & $\stackrel{1}{\circ}$ & $\ddot{\infty}$ & $\frac{0}{n}$ & $\begin{array}{l}\dot{1} \\
0\end{array}$ & $\begin{array}{l}\infty \\
0 \\
0\end{array}$ & $\begin{array}{l}0 \\
\infty \\
\text { is }\end{array}$ & in \\
\hline 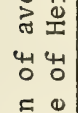 & & $\mid x$ & $\stackrel{\Rightarrow}{\Rightarrow}$ & $\ddot{v}$ & $\begin{array}{l}\hat{\sigma} \\
\text { in }\end{array}$ & $\begin{array}{l}\tilde{N} \\
\dot{J}\end{array}$ & $\begin{array}{l}\text { in } \\
\infty \\
0\end{array}$ & $\begin{array}{l}0 \\
\text { ํํ } \\
0 \\
0 \\
01\end{array}$ & $\begin{array}{l}\vec{m} \\
\text { in } \\
\Rightarrow\end{array}$ & $\begin{array}{l}\stackrel{0}{+} \\
\dot{-} \\
-1\end{array}$ \\
\hline 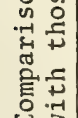 & 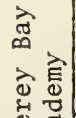 & in & $\begin{array}{l}0 \\
\text { i }\end{array}$ & $\begin{array}{l}0 \\
\dot{7}\end{array}$ & ? & 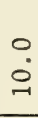 & $\stackrel{0}{-1}$ & $\begin{array}{l}1 \\
\vdots \\
i\end{array}$ & i & i \\
\hline $0^{\circ}$ & ${ }_{\Sigma}^{+}$ & $1 x$ & 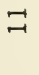 & $\tilde{N}$ & 눙 & $\vec{\sigma}$ & $\stackrel{\text { ㄱ. }}{\text { N }}$ & 1 & 1 & 1 \\
\hline त्र & 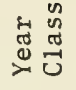 & & 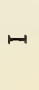 & બ & ๒ & $\exists$ & $>$ & $\stackrel{\mapsto}{\lessgtr}$ & $\stackrel{5}{\leftrightarrows}$ & $\begin{array}{l}\mapsto \\
\mapsto\end{array}$ \\
\hline
\end{tabular}


during the year and are highest in summer and fall and lowest in late fall and spring. The age structure of the clam population at Monterey Bay Academy is comprised of five classes, four of which appear to represent year classes.

\section{VII . SUMMARY}

1. Pismo clams in Monterey Bay are distributed between the Salinas River mouth and Santa Cruz. There are no clam beds south of the Salinas River.

2. The highest densities of clams occur in the intertidal zone or in the shallow subtidal zone. There were no extensive subtidal clam beds.

3. Intertidal Pismo clams appear as high as +2.6 feet above MLLW and the different size classes do not show a vertical separation.

4. The dispersion pattern of most intertidal clams is random.

5. The presence and absence of clams on beaches are statistically correlated with the slope of the beach and the grain size. Clams are found in beaches with slight slopes and smaller grain sizes.

6. Pismo clams have a 1:1 sex ratio and mature in their second year at about 20 millimeters in length.

7. The principal spawning period for Pismo clams in Monterey Bay is September and October. Some spawning also occurs during the summer months.

8. Juvenile Pismo clams grow more rapidly than adults at all times of the year.

9. The growth rate of clams varies at different times of the year. Growth is more rapid in late summer and early fall than in spring and late fall.

10. The growth rate is slower in Monterey Bay than southern California. 
ANSELL, A.D., "Reproduction, Growth and Mortality of Venus striatula (da Costa) in Kames Bay, Millport," Journal of Marine Bio Zogical Association of the United Kingdom, Vo1. 41, 1961, pp. 191-215.

BAXTER, J.L., "Results of the 1955 to 1959 Pismo Clam Censuses," California Department of Fish and Game, Vol. 42, No. 2, 1961, pp. 153-162.

BRETT, C.E., "A Portable Hydraulic Diver-Operated Dredge-Sieve for Sampling Subtidal Macrofauna," Journal of Marine Research, Vol. 22, No. 2, 1964, pp. 205-209.

BROENKOW, W.W., and BENZ, S.R., "Oceanographic Observations in Monterey Bay, California, January 1972 to April 1973," Technical Publication 73-3, Moss Landing Marine Laboratories, Moss Landing, Calif., 1973.

CASSIE, R.M., "Some Uses of Probability Paper in the Analysis of SizeFrequency Distributions," Australian Journal of Marine and Freshwater Research, Vol. 5, 1954, pp. 513-522.

COE, W.R., "Development of the Gonads and the Sequence of the Sexual Phases in the California Oyster (Ostrea lurida), "Technical Bulletin 3, Scripps Institute of Oceanography, University of California, La Jolla, Calif., 1932, pp. 119-144.

COE, W.R., "Nutrition, Growth and Sexuality of the Pismo Clam (Tivela stultorum)," Joumal of Experimental Zoology, Vol. 104, No. $\overline{1,1947,}$ pp. 1-24.

COE, W.R., "Ecology of the Bean Clam Donax gouldi on the Coast of Southern California, Ecology, Vol. 36, No. 3, 1953, pp. 512-513.

COE, W.R., and FITCH, J.E., "Population Studies, Local Growth and Reproduction of the Pismo Clam (Tivela stultorum), "Journal of Marine Research, Vo1. 9, No. 3, 1950, pp. 188-210.

DUNHILL, R.M., and ELLiS, D.V., "The Distribution and Ecology of Sublittoral Species of Macoma (Bivalvia) off Moresby Island and in Satellite Channel, near Victoria, British Columbia," Veliger, Vol. 12, 1969, pp. 207-219.

EMERY, K.O., "Rapid Method of Mechanical Analysis of Sands," Joumal of Sedimentary Petrology, Vo1. 8, 1938, pp. 105-111.

EMERY, K.0., "A Simple Method of Measuring Beach Profiles," LimnoZogy and Oceanography, Vol. 6, 1961, pp. 90-93. 
ELLIOTT, J.M., "Some Methods for the Statistical Analysis of Samples of Benthic Invertebrates," Science Publication 25, Freshwater Biological Association, 1971 .

FITCH, J.E., "A Relatively Unexploited Population of Pismo Clams, Tivela stultorum (Mawr 1823)," Proceedings, Malacological Society of London, Vo1. 36, No. 5, 1965, pp. 309-312.

FOLK, R.L., "A Review of Grain Size Parameters," Sediment, Vo1. 6, 1966, pp. 73-93.

FOLK, R.L., and WARD, W.C., "Brazos River Bar: A Study in the Significance of Grain Size Parameters," Journal of Sedimentary Petrology, Vol. 27, 1957, pp. 3-26.

FRASER, C.M., and SMITH, G.M., "Notes on the Ecology of the Butter Clam, Saxidomus giganteus," Transactions of the Royal Society of Canada, Series 3, Vo1. 22, No. 2, 1928, pp. 271-291.

GALTSOFF, P.S., "Physiology of Reproduction in Molluscs," American Zoology, Vol. 1, 1961, pp. 273-289.

GAUCHER, T.A., "Dispersion in a Subtida1 Mya arenaria (Linnaeus) Population," Proceedings of the National Shellfisheries Association, Vo1. 56, 1965, pp. 3-4.

GIESE, A.C., "Comparative Physiology: Annual Reproductive Cycle of Marine Invertebrates," Annual Review of Physiology, Vol. 21, 1959, pp. 547-576.

GIESE, A.C., et a1., "Seasona1 Changes in Body Component Indices and Chemical Composition in the Pismo Clam Tivela stultorum," Comparative Biochemistry and Physiology, Vol. 22, $\overline{1967, \text { pp. 549-561. }}$

HARDING, J.P., "The Use of Probability Paper for the Graphical Analysis of Polymodal Frequency Distributions," Journal of Marine Biological Association of the United Kingdom, Vo1. 28, 1949, pp. 141-153.

HERRINGTON, W.C., "The Pismo Clam, Further Studies of its Life History and Depletion," Fish Bulletin 18, California Department of Fish and Game, Sacramento, Calif., 1930, pp. 1-67.

HODGSON, A., Unpublished Report, Moss Landing Marine Laboratories, Moss Landing, Calif., 1973.

HOLME, N.A., "Population Dispersion in Tellina tenuis (da Costa)," Journal of Marine Biological Association of the United Kingdom, Vol. 29, 1950, pp. 267-280.

HUGHES, R.N., "Population Dynamics of the Bivalve Scrobicularia plana (da Costa) on an Intertidal Mud-Flat in North Wales," Journal of Animal Ecology, Vol. 3, No. 2, 1970, pp. 333-356. 
HUGHES, R.N., and THOMAS, M.L.H., "The Classification and Ordination of Shallow Water Benthic Samples from Prince Edward Island, Canada," Journal of Experimental Marine Biology and Ecology, Vol. 7, 1971, pp. $1-34$.

JACKSON, J.B.C., "Bivalves: Spatial and Size-Frequency Distributions of Two Intertidal Species," Science, Vol. 161, 1968, pp. 479-480.

KORRINGA, P., "Relations Between the Moon and Periodicity in the Breeding of Marine Animals," Ecological Monographs, Vol. 17, No. 3, 1947, pp. 347-381.

KOSLER, A., "Distributional Patterns of the Sublittoral Fauna Near the Isle of Hiddensee (Baltic Sea, Russia)," Marine Biology, Vo1. 1, 1968, pp. 266-268.

LEONARD, V.K., Jr., "Seasonal Gonadal Changes in Two Bivalve Mollusks in Tomales Bay, California," Veliger, Vo1. 11, No. 4, 1969, pp. 382-390.

LOOSANOFF, V., "Sexual Phases in the Quahog," Science, Vo1. 83, 1936, pp. 287-288.

LOOSANOFF, V., "Seasonal Gonadal Changes of Adult Clams Venus mercenaria (L.)," Biological Bulletin, Vo1. 72, Marine Biological Laboratory, Woods Hole, Mass., 1937, pp. 406-416.

LOOSANOFF, V., "Maturation of Gonads of Oysters, Crassostrea virginica, of Different Geographical Areas Subjected to Relatively Low Temperatures," Veliger, Vol. 11, No. 3, 1969, pp. 153-163.

LOOSANOFF, V., and DAVIS, H.C., "Rearing of Bivalve Mollusks," Advances in Marine Biology, Vol. 1, Academic Press, New York, 1963, pp. 1-136.

LORENZEN, C.J., "Vertical Distribution of Chlorophyll and Phaeo-Pigments: Baja, California," Deep-Sea Research, Vo1. 14, No. 5, Oct. 1967, pp. 735-745.

MASON, J., "A Possible Lunar Periodicity in the Breeding of Scallop, Pecten maximus (L.)," Annals and Magazine of Natural History, London, New Series, Vol. 13, No. 1, 1958, pp. 601-602.

MAURER, D., "Pelecypod-Sediment Association in Tomales Bay, California," Veliger, Vo1. 11, 1969, pp. 250-255.

MILEIKOVSKY, S.A., "The Influence of Pollution on Pelagic Larvae of Bottom Invertebrates in Marine Nearshore and Estuarine Waters," Marine Biology, Vo1. 6, No. 4, 1970, pp. 350-356. 
MOORE, D.R., and REISH, D.J., "Studies on the Mytilus edulis Community in Alamitos Bay, California - IV Seasonal Variation in Gametes from Different Regions on the Bay," VeZiger, Vol. 11, No. 3, 1969, pp. 250-255.

NELSON, T.C., "On the Distribution of Critical Temperatures for Spawning and for Cilliary Activity in Bivalve Molluscs," Science, Vol. 67, No. 1730,1928 , pp. 220-221.

OLIVER, J.S., and SLATTERY, P.N., "Dredging, Dredge Spoil Disposal and Benthic Invertebrates in Monterey Bay," Moss Landing Marine Biological Laboratories, Moss Landing, Calif., 1973.

ORTON, J.H., "Sea Temperature, Breeding and Distribution in Marine Animals," Journal of Marine Biological Association of the United Kingdom, Vol. 12, 1920 , pp. 339-366.

PORTER, H.J., "Seasonal Gonadal Changes in Adu1t Clams, Mercenaria mercenaria (L.) in North Carolina," Proceedings of the National Shellfisheries Association, Vol. 55, 1964, pp. 35-52.

PRATT, D.M., and CAMPBELL, D.A., "Environmental Factors Affecting Growth in Venus mercenaria," Limnology and Oceanography, Vo1. 1, 1956, pp. $\overline{2-17}$.

QUAYLE, D.B., "The Structure and Biology of the Larvae and Spat of Venerupis pullastia (Montagu)," Transactions of the Royal Society of Edinbuxgh, Vol. 62, 1952, pp. 255-297.

QUAYLE, D.B., and BOURNE, N., "The Clam Fisheries of British Columbia," Bulletin No. 179, Fisheries Research Board of Canada, Ottawa, 1972.

ROPES, J.W., and STICKNEY, A.P., "Reproduction Cycle of Mya arenaria in New England," Biological Bulletin, Vol. 128, Marine Biological Laboratory, Woods Hole, Mass., 1965, pp. 315-327.

ROPES, J.W., "Hermaphroditism in the Surf Clam, Spisula solidissima," Annual Reports of the American Malacological Union, 1966, p. 26.

SAHU, B.K., "Depositional Mechanisms from the Size Analysis of Clastic Sediments," Joumal of Sedimentamy Petrology, Vo1. 34, No. 1, Mar. 1964, pp. 73-83.

SASTRY, A.N., "Temperature Effects in Reproduction of the Bay Scallop, Aequipecten irradians Lamark.," Biological Bulletin, Vo1. 130, Marine Biological Laboratory, Woods Hole, Mass., 1966, pp. 118-134.

SASTRY, A.N., "The Relationship Among Food, Temperature and Gonad Development of the Bay Scallop, Aequipecten irradians Lamarck.," Physical Zoology, Vol. 41, 1968, pp. 44-53. 
SCRIPPS INSTITUTE OF OCEANOGRAPHY, "Surface Water Temperatures," Data Archives, La Jolla, Calif., unpublished, 1973.

SIMPSON, G.G., ROE, A., and LEWONTIN, R.C., Quantitative Zoology, Harcourt Brace \& World, New York, 1960.

SMETHIE, W.M., "Some Aspects of the Temperature, Oxygen and Nutrient Distributions in Monterey Bay, California," Technical Publication 73-1, Moss Landing Marine Laboratories, Moss Landing, Calif., 1973.

SOKAL, R.R., and ROHLF, F.J., Biometry, Freeman and Co., San Francisco, Calif., 1969.

SWAN, E.F., "The Growth of the Clam Mya arenaria as Affected by the Substratum," Ecology, Vol. 33, 1952, pp. 530-534.

U.S. DEPARTMENT OF COMMERCE, "Surface Water Temperatures at Tide Stations, Pacific Coast," Special Publication No. 280, 5th ed., Superintendent of Documents, Washington, D.C., 1956.

WAIDELICH, R., Unpublished Report, Moss Landing Marine Laboratories, Moss Landing, Calif., 1973.

WEYMOUTH, F.W., "The Life History and Growth of the Pismo Clam," Fish Bulletin No. 7, California Department of Fish and Game, Sacramento, Calif., 1923.

WOOLF, C.M., Principles of Biometry, Van Nostrand, New York, 1968.

YOUNG, R.T., "Spawning Season of the California Musse1 Mytilus californianus," Ecology, Vol. 23, 1942, pp. 490-492. 



\section{APPENDIX}

\section{STATISTICAL TESTS}

\section{Chi-square Test.}

The chi-square test is a nonparametric test used to determine the significance of differences between two sets of data which consist primarily of frequencies. This includes "goodness-of-fit" tests concerned with testing whether observed sample frequencies fit a theoretical or hypothetical frequency. In this report all uses of chi square have been for goodness-of-fit.

The variance to mean ratio $\left(s^{2} / \bar{x}\right)$ should be one for a random distribution, less than one for a regular distribution, and greater than one for a clumped distribution. The formula for testing the variance to mean ratio is:

$$
x^{2}=\frac{s^{2}(n-1)}{\bar{x}}
$$

where:

$$
\begin{aligned}
& \mathrm{s}^{2}=\text { variance } \\
& \overline{\mathrm{x}}=\text { mean } \\
& \mathrm{n}=\text { number of observations } .
\end{aligned}
$$

Significant deviation from a random distribution is determined from a nomogram in E11iott (1971).

Chi square was also used in a second test to determine if the clam sex ratios differed from a theoretical frequency of one to one or 50 percent males and 50 percent females. In this case the formula for chi square is:

$$
x^{2}=\Sigma \frac{(o-e)^{2}}{e}
$$

where:

$$
\begin{aligned}
& o=\text { observed frequency } \\
& \mathrm{e}=\text { expected frequency }
\end{aligned}
$$

The chi square is then compared to a table for one degree of freedom at the selected level of rejection (usually 5 percent). A value of chi square exceeding the tabled value is evidence of a significant deviation from the theoretical value. 
2. One-way Analysis of Variance.

This is a parametric statistical test which tests for differences among more than two groups of samples classified by a single criterion, e.g., to see if more of the total variability in the data is among the several different samples or within the individual samples. A significant difference means that more of the variability is among groups rather than within groups.

The significant test used was an F test, a test of variance. This test was used, because testing was one among several groups, and there were few tests outside of analyses of variance which were available to do such tests.

Formulas for the test are:

\begin{tabular}{|c|c|c|c|}
\hline $\begin{array}{l}\text { Source of } \\
\text { variation }\end{array}$ & $\begin{array}{c}\text { Degrees of } \\
\text { freedom }\end{array}$ & Sums of squares & Mean square \\
\hline Among group & $c-1$ & $c_{\Sigma} \frac{\left({ }^{n} \Sigma y\right)^{2}}{n_{i}}-\frac{\left({ }^{c} \Sigma^{n} \Sigma y\right)^{2}}{n}$ & $\frac{S S}{c-1}$ \\
\hline Within group & $n-c$ & Tota1-among group & $\frac{S S}{n-c}$ \\
\hline Tota1 & $n-1$ & $c_{\Sigma} n_{\Sigma y}{ }^{2}-\frac{\left({ }^{c}{ }^{n} \Sigma y\right)^{2}}{n}$ & \\
\hline
\end{tabular}

where: $\quad c=$ number of columns

$\mathrm{n}=$ number of observations

The test is an $F$ test where:

$$
F=\frac{\text { Mean square among group }}{\text { Mean square within groups }}
$$

$F$ is compared to tabled $F$ values for the appropriate degrees of freedom. An F value exceeding the tabled value indicates significant differences among groups.

\section{Student-Newman-Keuls Multiple Range Test.}

This an a posteriori step-wise test used to measure differences among several means. It differs from the one-way analysis of variance by testing means not variances, and is used after the analysis of variance has indicated the need for the test. 
The test was used to check groups of stations for differences in mean densities after the analysis of variance had indicated that the stations differed. This test refined the analysis of variance by finding groups of densities which were different from others. This could not be done by the analysis of variance which merely indicated differences among all stations as a group.

Formulas for this test are:

$$
\mathrm{S}_{y}=\sqrt{\frac{\text { Mean square within }}{n}}
$$

$\operatorname{LSR}$ (for $\mathrm{k}$ groups) $=\mathrm{Q} \times \mathrm{S}_{\bar{y}}$

where: mean square within = the mean square from analysis of variance and $\mathrm{n}$ is the number of replicates per group.

$$
\begin{aligned}
Q= & \text { studentized range taken } \\
& \text { from a table such as U } \\
& \text { in Sokal and Rohlf, } 1969 .
\end{aligned}
$$

It is also necessary to subtract each mean from each other one and compare with. LSR figures. Values exceeding the LSR figure are an indication of significant difference.

4. Mann-Whitney U Test.

This is a nonparametric test used to test the differences between two sets of samples, and if two independent samples could have been drawn from the same population. It is the nonparametric alternative to a parametric $t$ test and is used if the data being tested are not from a normally distributed population.

This test was used in comparing clams on two beaches because it was uncertain the clam populations were normally distributed.

Formulas for this test are:

$$
U=n_{1} n_{2}+\frac{n_{1}\left(n_{1}+1\right)}{2}-R_{1}
$$

where:

$$
\begin{aligned}
& \mathrm{n}_{1}=\text { number of observations in group } 1 \\
& \mathrm{n}_{2}=\text { number of observations in group } 2 \\
& \mathrm{R}_{1}=\text { sum of the ranks assigned in group } 1
\end{aligned}
$$




$$
U^{\prime}=n_{1} n_{2}-U
$$

After calculation of $U$, the calculation of $U^{\prime}$ is made. The 1 arger of two values is used as the test statistic. It is compared to a table of $U$ values, and if the calculated value exceeds the tabled value at the selected level of probability, this is taken as evidence of a significant difference between the two groups.

5. Spearman Rank Correlation.

This is a nonparametric test which measures the association or correlation between two variables. It is the nonparametric equivalent of the parametric correlation coefficient and is used if the variables under consideration are not normally distributed.

The test was used because of the assumption that the abundances of clams and the sediment parameters were normally distributed.

The formula for this test is:

$$
r_{s}=1-\left[\frac{6 \Sigma \mathrm{d}_{i}^{2}}{\mathrm{~N}^{3}-\mathrm{N}}\right]
$$

where:

$$
\begin{aligned}
\mathrm{d}_{\mathrm{i}}{ }^{2} & =\text { the squared difference in two ranks } \\
\mathrm{N} & =\text { total number of paired observations }
\end{aligned}
$$

The Spearman rank coefficient, $r_{s}$, calculated as above, is then compared to a tabled value. If the calculated $r_{s}$ exceeds the tabled $r_{s}$ value at the appropriate level of probability ${ }^{\text {it }}$ is taken as evidence of a significant correlation.

\section{Linear Regression.}

This is a parametric analysis which measures how much increase or decrease in one factor may be expected from a unit increase in the other. The results of a regression analysis are given in the form of an equation which relates one variable to the other. The general form of the regression equation is:

$$
\mathrm{Y}=\mathrm{a}+\mathrm{b}_{y \cdot x^{\mathrm{x}}}
$$

where: 


$$
\begin{aligned}
& \mathrm{Y}=\text { dependent variable } \\
& \mathrm{a}=\mathrm{Y} \text { intercept at } \mathrm{x}=0 \\
& \mathrm{~b}=\text { slope of the line } \\
& \mathrm{x}=\text { independent variable }
\end{aligned}
$$

The calculation in linear regression is for $b$ and for $a$.

This analysis in growth was used because it is the best way to establish fits for scatter diagrams which relate growth increment to initial size.

The formulas used to establish the equation are:

$$
\begin{aligned}
b_{y \cdot x} & =\frac{\sum x y-\frac{(\Sigma x)(\Sigma y)}{n}}{\Sigma x^{2}-\frac{(\Sigma x)^{2}}{n}} \\
a & =\bar{Y}-b_{y \cdot x} \bar{X}
\end{aligned}
$$

where $\bar{Y}$ and $\bar{X}$ are the means of the respective variables.

Tests of significance in regression involve testing $b$ values to see if they are different from 0 or any other $b$ value. These tests are best accomplished with $t$ tests by:

$$
t=\frac{\left(b_{y} \cdot x^{-0)}\right.}{s_{b}}
$$

where $s_{b}=$ standard error of the regression coefficient.

$A \quad t$ value greater than the tabled $t$ value at the appropriate level of probability is evidence of a significant difference. 



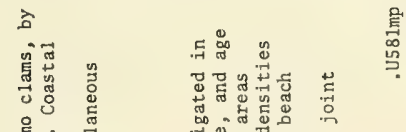

易的

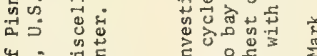

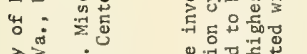

के क्षे

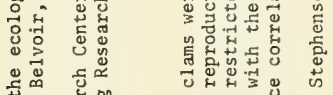

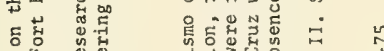

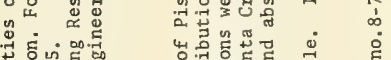

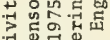

प्ले

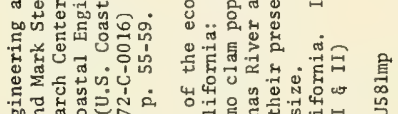

舟

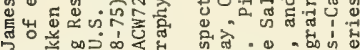

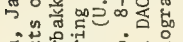

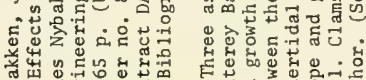

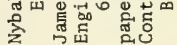

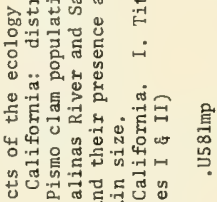

.

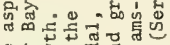

F

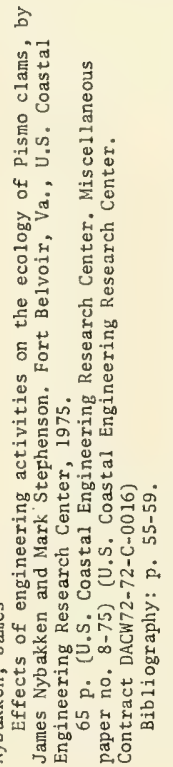

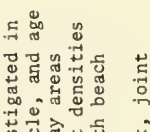

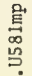

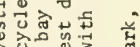

至

ลิ

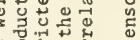

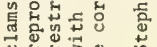

(a)

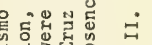

in
$\vdots$
$\dot{1}$
$\dot{c}$

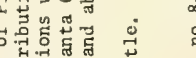

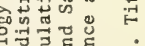

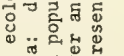

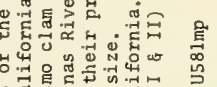

का नु है

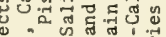

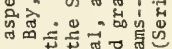

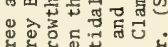

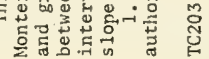

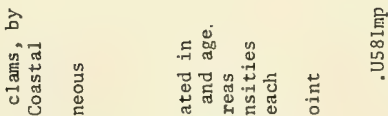

ए

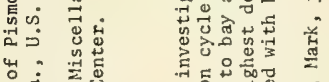

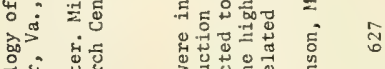

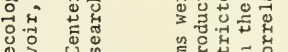

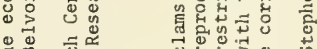

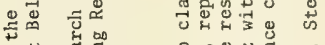

ᄃ

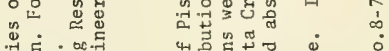

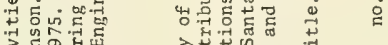

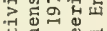

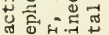

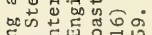

돈 805

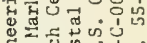

न

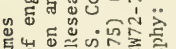

政出他

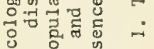

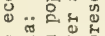

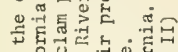

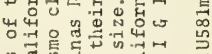

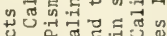

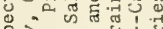

खे ले

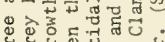

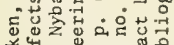

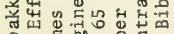

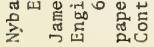

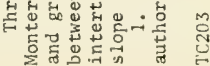

อิ

if

.

ज्ञ जू

फ्य :

के

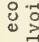

品

บู

ธี ั.

(4).

में एं

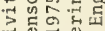

है है. त्र

or क क त 50

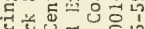

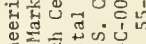

تิ

हुสำ ซु

แั

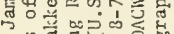

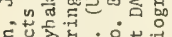

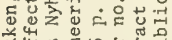

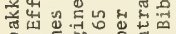

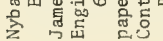

.

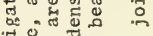

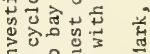

ᄃํํㄹ

芑艺可

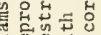

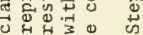

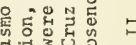

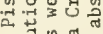

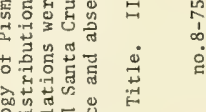

용그름

ข.. E

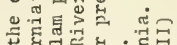

फ

出出울

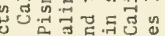

口 कौ है क्न

क्षें

\%

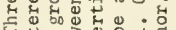

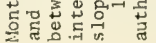





\begin{tabular}{|c|c|c|c|c|c|}
\hline 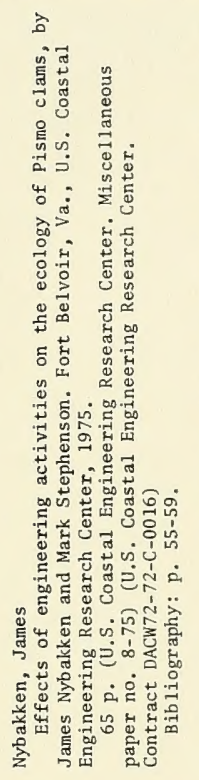 & 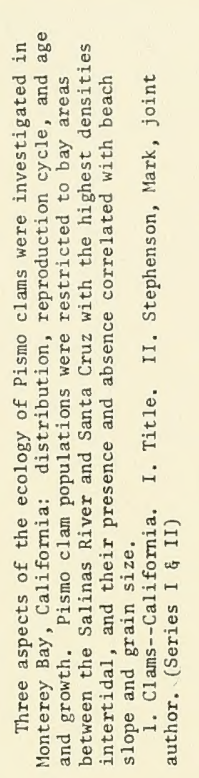 & 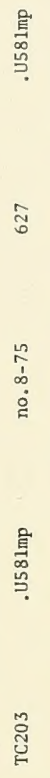 & 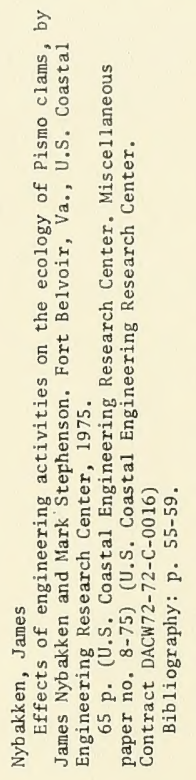 & 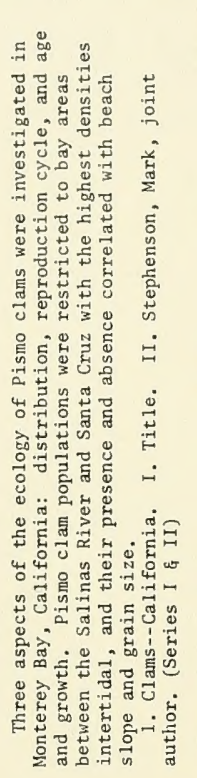 & $\begin{array}{l}\text { 官 } \\
\text { D } \\
\stackrel{0}{?}\end{array}$ \\
\hline 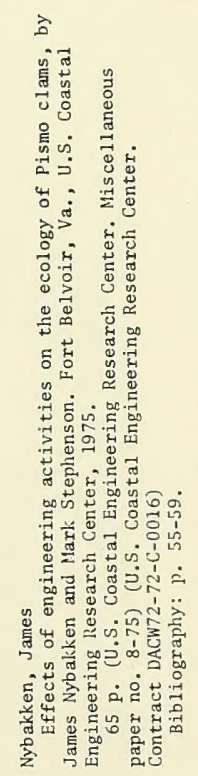 & 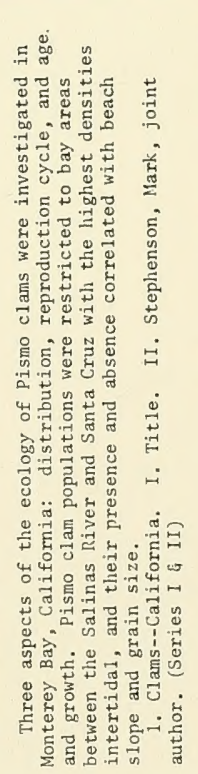 & $\begin{array}{l}\stackrel{R}{0} \\
\dot{1} \\
\infty \\
\dot{g}\end{array}$ & 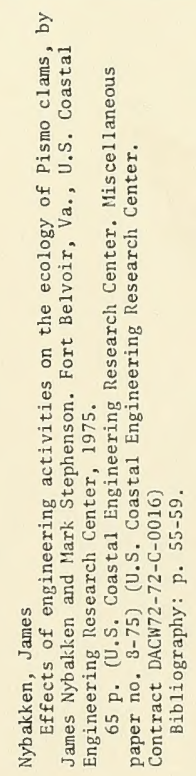 & 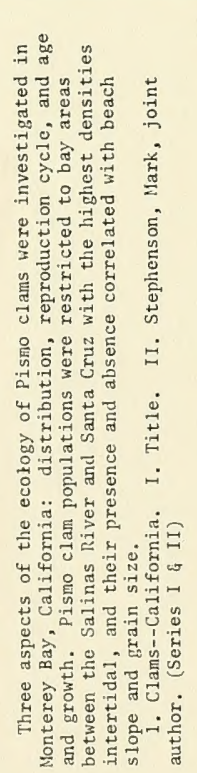 & 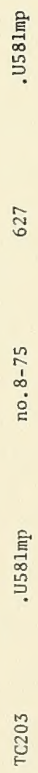 \\
\hline
\end{tabular}



WHOI DOCUMENT COLLECTION 
